\title{
Two decades of variable retention in British Columbia: a review of its implementation and effectiveness for biodiversity conservation
}

\author{
William J. Beese ${ }^{1 *} \mathbb{D}$, John Deal ${ }^{2}$, B. Glen Dunsworth ${ }^{3}$, Stephen J. Mitchell ${ }^{4}$ and Timothy J. Philpott ${ }^{5}$
}

\begin{abstract}
Stand-level retention is an important component of sustainable forest management which aims to balance ecological, social and economic objectives. Long-term retention of mature forest structures at the time of harvesting (variable retention) is intended to produce future forest stands that more closely resemble conditions that develop after natural disturbances, thereby maintaining greater diversity of habitats for a variety of organisms. Structure includes features such as live and dead trees representing multiple canopy layers, undisturbed understory vegetation and coarse woody debris. Over the past two decades, variable retention has become common on forest lands in the temperate rainforests of coastal British Columbia (BC) and has been applied to a lesser extent in inland forest types. Our review of studies in BC and in similar forest types in our region indicates that both aggregated and dispersed retention can contribute to biodiversity conservation by providing short-term 'life-boating' habitat for some species and by enhancing the structural characteristics of future stands. For example, greater abundance of species present in the pre-harvest forest have been documented for vegetation, birds, carabid beetles, gastropods, ectomycorrhizal fungi and soil fauna in retention cutblocks compared to clearcuts. There are, however, some negative consequences for timber production such as wind damage to retained trees and reduced growth rates of tree regeneration compared to clearcuts. The authors suggest an adaptive management approach for balancing competing objectives when faced with uncertainty. This includes monitoring the implementation and effectiveness of various strategies for achieving goals. Over two decades of experience applying variable retention harvesting to industrial-scale management of forest lands in BC suggests that it is possible to balance production of wood with biodiversity conservation.
\end{abstract}

Keywords: Alternative silvicultural systems, Clearcutting, Biological legacies, Forest biodiversity, Old-growth, Variable retention, British Columbia

\section{Background}

Forest ecosystems and associated species have evolved in response to climate, other biophysical attributes and a range of natural disturbances at various temporal and spatial scales. Ecologically based forest management aims to conserve biological diversity and forest productivity, in part, by using natural disturbance patterns and processes to guide stand- and forest-level interventions and resulting vegetation structures (e.g. Hunter 1990).

\footnotetext{
* Correspondence: bill.beese@viu.ca

'Vancouver Island University, 900 Fifth Street, Nanaimo, BC V9R 5S5, Canada Full list of author information is available at the end of the article
}

The foundations and principles of ecological (i.e. ecosystem based, ecologically based, etc.) forest management have several origins (D'Amato et al. 2017) but this approach has been most recently articulated in a comprehensive manner by Franklin et al. (2018). Palik and D'Amato (2017) discuss the importance of understanding the distinction among terms for these approaches that foresters may use carelessly. As a hierarchy, ecological forestry is a framework of ecological principles and goals, natural disturbance emulation is a strategy and retention harvesting is a practice. In the past 30 years, various approaches to ecologically based forestry have 
become common in the province of British Columbia (BC), Canada as part of sustainable forest management systems that aim to integrate environment, social and economic goals, often guided by forest certification schemes (van Kooten et al. 2005).

Compared to other parts of the world, commercial use of $\mathrm{BC}$ 's forests progressed from exploitation to a highly regulated and ecologically based framework in a relatively short period of time, notwithstanding millennia of forest use by indigenous peoples using traditional ecological knowledge (Chisholm 2013). Here, we provide a very brief account of this transition. Industrial-scale logging increased rapidly in BC during the 1950s through 1970s with the government's expansion of volume-based licenses to forest companies in public sustained yield units (now timber supply areas) and area-based tenures such as Tree Farm Licences (BC Ministry of Forests and Range 2012). Harvest levels peaked in the middle 1980s, except for spikes in more recent years due to salvage harvesting from mountain pine beetle mortality (Environmental Reporting BC 2018). Eventually, the desire for other values from forests besides timber led to a clash with large-scale clearcutting in the late 1980s and early 1990s. Alternatives to clearcutting became a focus of research in the early 1990s throughout BC (Arnott and Beese 1997; Vyse et al. 2005; Wiensczyk 2012). In the summer of 1993, protests against logging in Clayoquot Sound (a 350,000 ha region on the west coast of Vancouver Island) under a BC government land use decision became the largest act of civil disobedience in Canadian history with over 850 people arrested (Tindall and Robinson 2017). Part of the BC government response was to set up the Scientific Panel for Sustainable Forest Practices in Clayoquot Sound (aka Clayoquot Scientific Panel or CSP), whose mandate was to 'develop world-class standards for sustainable forest management by combining traditional and scientific knowledge' (CSP 1994). The panel included academic specialists as well as four indigenous members from the Nuu-chah-nulth First Nations. One of the panel's recommendations was to leave a portion of the original forest stand behind during harvesting using a more ecologically based approach to harvesting and silvicultural systems it called variable retention ${ }^{1}$ (CSP 1995). The BC government introduced the Forest Practices Code in 1994, which set stand- and landscape-level retention targets for BC public forests (Province of BC 1995).

In 1998, MacMillan Bloedel, one of the region's largest forest companies at the time, adopted a strategy to replace conventional clearcutting with variable retention and to increase conservation of old-growth forests. Other companies in BC followed, adopting variable retention for varying proportions of their harvesting, especially in coastal old-growth forests. BC's publicly owned forests remain a significant source of industrial wood through long-term forest management licences with forest companies. Forest stewardship plans approved by government must manage resources for multiple economic, social and environmental values. While stand-level retention has become an important strategy for helping to achieve biodiversity conservation goals, such as 'life-boating' of mature-forest species and structural enrichment of future stands, there are potential conflicts with the traditional goals of silviculture and timber management. The authors believe that it is timely to assess the outcomes of variable retention in $\mathrm{BC}$ now that many initial effects are known. Although our focus is regional rather than global, BC provides a useful case-study for other jurisdictions because of the large number of hectares harvested using variable retention.

The objectives of this paper are to (1) summarize the application of variable retention in British Columbia over the past 20 years, (2) describe adaptive management and monitoring initiatives that were established to evaluate the outcomes of the approach and (3) review the findings from monitoring and research to assess whether or not the goals of variable retention are being achieved.

\section{Origins and goals of variable retention}

Variable retention is based on the pioneering work with 'green tree retention' in the Pacific Northwest region of the USA that was described by Franklin et al. (1997). The variable retention approach maintains structural elements of the pre-harvest stand throughout a harvested area to achieve specific objectives. Variable retention follows a natural disturbance-based management paradigm-recognizing the importance of structural complexity to forest ecosystem function and biological diversity. Live and dead trees of varying sizes and canopy layers, and coarse woody debris are retained as habitat for a host of organisms. Of particular focus is the maintenance of biological legacies when harvesting older forests (Lindenmayer and Franklin 2002; Beese et al. 2003; Franklin et al. 2018).

Naturalistic silvicultural systems that attempt to maintain natural forest structure and dynamics are not new to forestry and have long been recognized as a means for reducing economic and ecological uncertainty (e.g. Bruenig and Klemp 2000). For example, the single tree selection system has been used to regulate yield and maintain continuous cover in uneven-aged forests for over 100 years. In the classical silvicultural systems (i.e. patch, clearcut, seed-tree, shelterwood and selection), maintaining or improving yield by enhancing conditions for regeneration and improving the quality of the growing stock are paramount. In variable retention stands, the retained trees may be very old, of poor timber quality and low vigor, with features that increase their value for wildlife habitat. Overstory influence is retained over the majority of the opening throughout the rotation, even at the expense of the 
growth and vigor of regeneration and sapling layers (Mitchell and Beese 2002). Multiple age classes may be retained, not to balance age class distribution, but to emulate age class distributions typical of natural disturbances.

\section{Global application of retention forestry}

Retention has been applied in many forest types around the world (Gustafsson et al. 2012). The most widespread use has been in western Canada and the USA, Australia (mostly Tasmania), Argentina and Europe (particularly the Nordic countries) with documented benefits for conservation of biological diversity in forest stands during the initial years following harvesting (e.g. Rosenvald and Lõhmus 2008, Aubry et al. 2009, Craig and Macdonald 2009, Baker and Read 2011, Fedrowitz et al. 2014, Soler et al. 2016). Lindenmayer et al. (2012) present a case for widespread adoption of the retention approach to meet sustainability goals for the vast majority of the world's forests that are outside of formal protected areas and are not intensive forest plantations. They argue that an intermediate approach between protection and plantations, which integrates multiple values, is broadly applicable to diverse forest types and is an essential supplement to large protected areas.

\section{Retention silvicultural system in $B C$}

A variety of terms and uses appear in the literature on stand-level retention. In $\mathrm{BC}$, we make a distinction between the terms variable retention (VR) and the retention system. We use variable retention to describe the overall approach to forest harvesting that requires long-term retention of trees and associated habitat. VR can utilize traditional silvicultural systems, such as shelterwood or selection, to meet forest regeneration objectives. We use the term retention system to refer to a specific silvicultural system designed to meet the goals of VR, which was originally defined in the BC Operational Planning Regulations (FPC 1999). This silvicultural system has three requirements: (1) retained trees are distributed over the area of the cutblock, (2) standing trees are left for the long term (at least one rotation) and (3) distribution of leave trees achieves $>50 \%$ 'forest influence' (i.e. the area surrounding a tree or forest edge with a radius equal to the tree height). This new silvicultural system acknowledges that retention of trees and other structural attributes of forests for purposes other than tree regeneration and timber production are legitimate goals of forest management (Mitchell and Beese 2002). The two main variants of the retention system are group (or aggregated) and dispersed. For safety, economic and ecological reasons, aggregated retention is often preferred; however, both variants and mixed approaches may be used to meet specific objectives (Franklin et al. 1997, 2018). The retention system normally uses a one-pass harvesting approach, but may also be prescribed with several harvesting entries using a wide range of logging systems, including ground-based, cable and helicopter (Beese et al. 2003).

We also use the term clearcut with reserves-a modification of traditional clearcutting where trees are retained within or adjacent to the cutblock (Helms 1998). This approach differs from the retention system in two ways: (1) there is no spatial distribution requirement for the reserves, so they generally do not meet the $>50 \%$ forest influence rule; and (2) the reserves need not be left for the long term. Some view the term 'clearcut with reserves' as an oxymoron which does not clearly convey the management intent. In practice, because clearcut with reserves usually does result in long-term retention, it can be an effective tool within a landscape-level biodiversity strategy. Where at least some long-term reserves are distributed within the cutblock, the approach can be quite similar to the retention system in both appearance and function.

\section{Overview of variable retention implementation in $B C$}

Forests and forest policy context

British Columbia has diverse biomes, including coastal and inland temperate rainforests, dry intermountain plateaus, subalpine and alpine areas and sub-boreal and boreal forests. The province's ecosystems are classified into 16 zones and numerous subzones and variants using the biogeoclimatic ecosystem classification system (Klinka et al. 1991). Forests cover $58 \%$ of the total land area of BC (55 of 95 million ha). The forests are 83\% coniferous, dominated by lodgepole pine (Pinus contorta Douglas ex Loudon), spruce (Picea spp.), Douglas-fir (Pseudotsuga menziesii (Mirb.) Franco) and true fir (Abies spp.) in the drier inland (interior) forests, and Douglas-fir, western hemlock (Tsuga heterophylla (Raf.) Sarg.), true fir, western redcedar (Thuja plicata Donn ex D. Don) and Sitka spruce (Picea sitchensis (Bong.) Carr. in the rainforests ( $\mathrm{BC}$ Ministry of Forests, Mines and Lands, BCMFL 2010). The diverse forest and alpine tundra ecosystems of $\mathrm{BC}$ are characterized by five natural disturbance types, which use the frequency of standinitiating or stand-maintaining events to classify forests (Province of BC 1995). Natural forests on the BC coast are typically influenced by infrequent or rare standinitiating events, while forests in the $\mathrm{BC}$ interior have a significant proportion of forests with frequent standinitiating events or frequent stand-maintaining fires.

Under Canada's political system, most forest classified as productive and available for timber harvesting in $\mathrm{BC}$ (24 million ha) is administered by the Provincial government (92\%) with very little Federal land. There are a growing number of areas managed by First Nations (indigenous peoples). About $8 \%$ of BCs productive forests 
are privately owned. The ten largest forest companies in BC have $42 \%$ of the harvesting rights on public land (BCMFML 2010). About $14 \%$ of BC's forests (7.6 million ha) are in formal Parks and protected areas and 59\% of the protected forest area is forest $>140$ years old. About 23\% of all forests over 250 years old are protected, and an estimated $50 \%$ of all forest $>140$ years old will not be harvested (BCMFML 2010).

The BC Forest and Range Practices Act (BC-FRPA 2002) and associated regulations governing public land require average stand-level wildlife tree retention of at least $7 \%$ of the area of cutblocks harvested over a 1-year period, with a minimum of $3.5 \%$ in any single cutblock; minimum coarse woody debris levels are also required (FPPR 2004). Some regional land-use plans require 15\% stand-level retention (e.g. Clayoquot Sound, Great Bear Rainforest). In addition, Old Growth Management Areas, riparian reserves and numerous reserves for wildlife and other resource values are required at the landscape level. Old-growth reserve requirements vary from 7 to $28 \%$ based on natural disturbance type and biodiversity emphasis zoning (Province of BC 1995). Individual companies may set voluntary targets for higher levels of retention under Forest Stewardship Plans, to meet or exceed certification requirements, or apply scientific results to maintain biodiversity. Over 50 million ha of BC's forest land is certified under independent sustainable forest management systems (Forest Products Association of Canada 2019). The three major systems are the Canadian Standards Association (CSA), Sustainable Forestry Initiative (SFI) and Forest Stewardship Council (FSC). Retention is a key component of the criteria and indicators for harvesting practices. Certification and streamside tree retention requirements are the primary influences on retention practices of private forest owners, governed by the Private Managed Forest Land Act (2003).

The variable retention approach is primarily implemented using the 'retention silvicultural system' (FPC 1999) and 'clearcut with reserves' as defined above. Aggregated (group) retention is the most common application of the approach, although single dispersed trees are often left in combination with aggregates. Aggregate size is typically $0.25-1$ ha, anchored on riparian areas (required buffers) or other important ecological features. Retention must remain for at least one rotation, but the intention is that most will never be cut. Typical retention levels average $20 \%$ in coastal rainforests, and less in interior forests, not including landscape-scale reserves.

\section{History of VR adoption and spread in BC}

The announcement in June 1998 by MacMillan Bloedel (MB) that it would use VR for virtually all forest harvesting - at the time the largest forest company operating on the BC coast-shocked the forest industry (Chipello 1998).
Prior to this time, partial-cutting silvicultural systems had been rarely employed in either the second-growth or oldgrowth forests of the $\mathrm{BC}$ coast by large companies; they were largely regarded as experimental or used by small woodlot owners (Arnott and Beese 1997; Macy 2011). Following MB's lead, other forest companies in coastal BC adopted VR for varying proportions of their harvesting. Weyerhaeuser purchased $\mathrm{MB}$ in 1999 and continued phase-in of the VR approach throughout its BC coastal operations over a 5-year period, completing over $90 \%$ of harvesting using VR in 2003. After several changes in ownership and a merger of three companies, use of VR has continued under Western Forest Products Inc. (Western) as part of the 'Western Forest Strategy' for managing over 1.6 million ha of forest land on the $\mathrm{BC}$ coast (Western 2018). Through 2018, more than 96,600 ha have been harvested using the retention system on Western's and predecessor companies' private land and public tenures (Fig. 1). The drop in total harvested area and the percentage of the retention system used from 2007 to 2009 reflects the change in landbase resulting from company mergers, reduced overall harvesting due to poor market conditions and a revised strategy. Implementation and monitoring showed that the retention system was not suitable for all sites (e.g. extensive damage to retention in windward areas, and high costs on cable harvested sites), so the $100 \%$ retention system (i.e. no clearcutting) goal was replaced with regional and ecosystem-based targets. The retention system continues to be used for about $60 \%$ of Western's harvesting-more than double the coastal average.

The use of stand-level retention has risen steadily over the past 20 years in BC (Fig. 2); however, most has been done using clearcut with reserves rather than the retention system. For all of BC (1998-2017), 3.4\% of harvesting on public lands used the retention system, $4.4 \%$ used other forms of partial cutting (i.e. seed tree, shelterwood, selection, thinning), $62 \%$ clearcut with reserves and $30 \%$ clearcut (Province of BC 2019). About 95\% of the area harvested using the retention silvicultural system has been on the coast, which is roughly one-third of BC's forest area. For the BC coast, $29 \%(64,828$ ha) of harvesting on public lands used the retention system over the 12-year period 2006 through 2017. The use of conventional clearcutting has gone from $88 \%$ of the $\mathrm{BC}$ public land harvest in 1998 to $14 \%$ in 2017. The difference in adoption of variable retention and retention system terminology between the $\mathrm{BC}$ coast and interior can be attributed to less public pressure on clearcutting and old-growth issues, and larger, more frequent natural disturbances (e.g. fire, insects) within interior regions. This is illustrated by the different maximum clearcut sizes allowed under $\mathrm{BC}$ regulations (40 ha, coast; 60 ha, interior; FPPR 2004). Actual average cutblock sizes in $\mathrm{BC}$ are considerably smaller than the maxima (16 ha, coast; 23 ha, all of $\mathrm{BC}$; Province of $\mathrm{BC}$ 


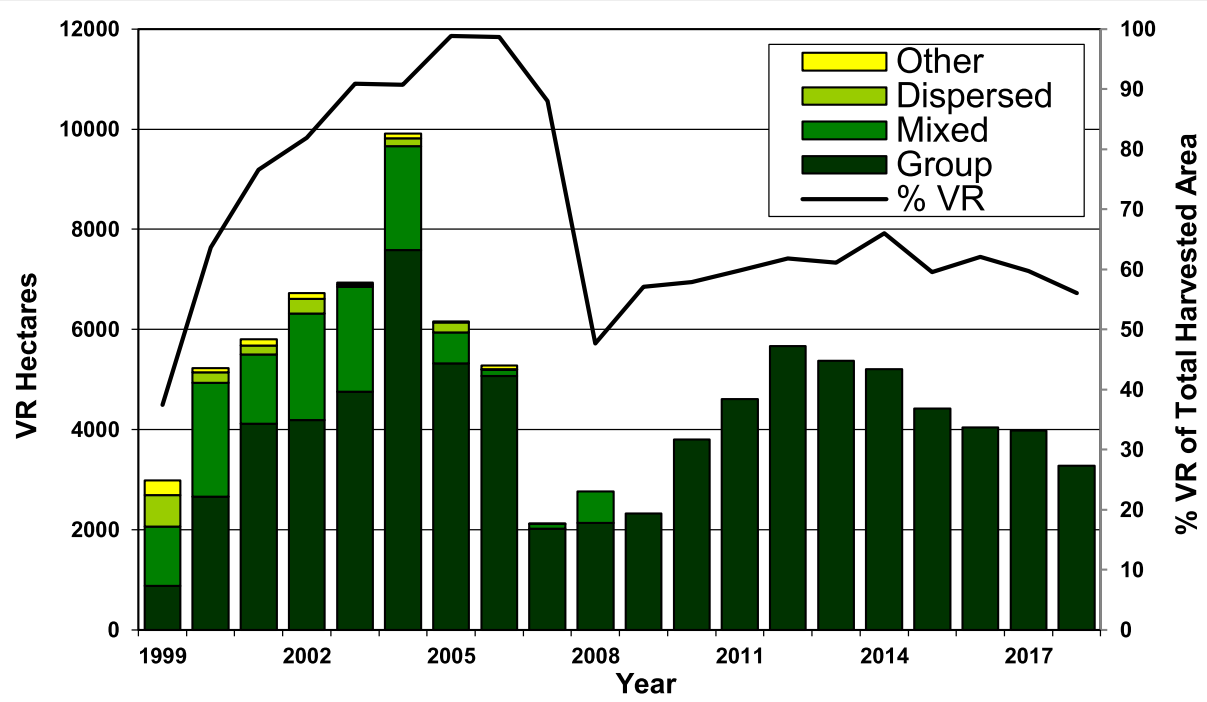

Fig. 1 Percent of total harvested area using variable retention (line) and area harvested (bars) using different variable retention types over 20 years by MacMillan Bloedel/Weyerhaeuser/Cascadia (1999-2006) and Western Forest Products (2007-2018) in BC Coastal forest operations. Total area through 2004 includes private lands (now Island Timberlands). Group = aggregated retention with groups predominantly 0.25 ha or larger; Dispersed = single trees or small clusters of trees spread across a cutblock; Mixed = both group and dispersed retention in the same cutblock; Other = patch cut,

shelterwood or selection systems (with long-term reserves). Retention type was not tracked after 2008 because nearly all VR was aggregated retention

2019). Also, not all foresters in Canada have embraced the new terminology (Groot et al. 2005).

\section{Application of variable retention under special land use plans} Standards for application of VR vary from BC provincial defaults where there is a 'higher level' regional land use plan, such as in Clayoquot Sound. The Clayoquot
Scientific Panel prescribed minimum retention levels for areas without significant values for resources other than timber (15\%) and high levels (70\%) for areas with significant non-timber values or sensitive features (CSP 1995). The principles and practices defined by the CSP and in several Clayoquot Sound Watershed Plans completed 2003-2006 guide landscape- and stand-level

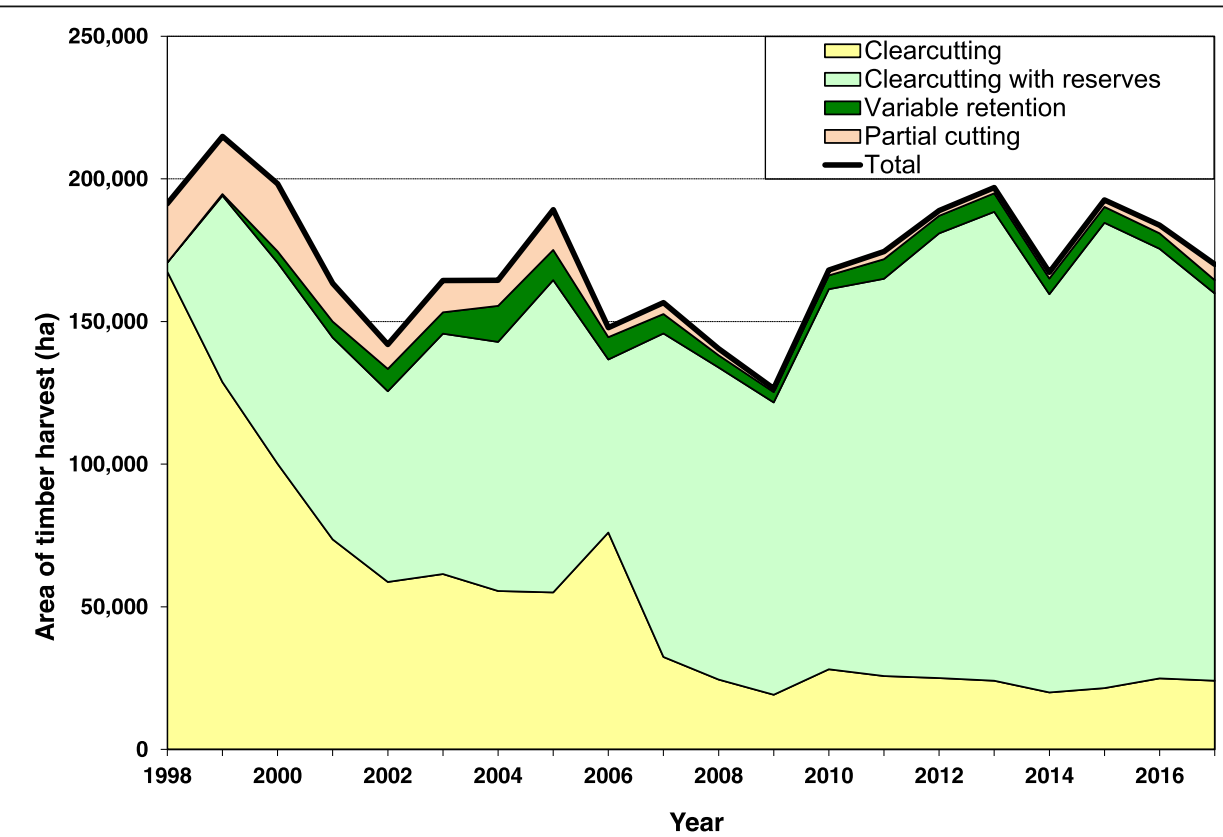

Fig. 2 Area harvested by silvicultural system over 20 years (1998-2017) on BC public lands. 'Partial cutting' includes seed tree, patch cut, shelterwood and selection systems, and intermediate cuts (e.g. thinning). Data from the Province of BC, Silviculture Statistics (https://www2.gov. bc.ca/gov/content/industry/forestry/managing-our-forest-resources/silviculture/silviculture-statistics) (accessed 15 Mar 2019) 
practices (Province of BC 2008). In the years following the CSP report, implementation of harvesting was slow because of new planning requirements. The CSP recommendations and subsequent adjustments reduced the allowable annual cut (AAC) from $900,000 \mathrm{~m}^{3}$ to $290,000 \mathrm{~m}^{3}$, largely due to the $61 \%$ of the forested landbase reserved from harvesting. About $88,000 \mathrm{~m}^{3}$ were harvested annually (roughly 130 ha/year) between 1996 and 2008 in Clayoquot under the variable retention guidelines, significantly below the AAC (Mychajlowycz 2010).

On the central and north coast of BC (aka Great Bear Rainforest), an ecosystem-based management (EBM) approach was adopted for land use plans covering a 7.5 million ha area (Coast Information Team 2004). Under EBM, at least 15\% stand-level retention must be left at the time of harvest within the context of a high proportion of landscape reserves and protected areas (i.e. about $70 \%$ of the natural range of old-growth forest will be reserved). Higher stand-level retention percentages apply to certain riparian and wetland ecosystems (Province of BC 2016). The Great Bear Rainforest is divided into two timber supply areas (as of January 2017), each with an AAC of about $800,000 \mathrm{~m}^{3}$ apportioned among roughly ten licencees (BC Ministry of Forests, Lands and Natural Resource Operations, BCMFLNRO 2016).

In Haida Gwaii (aka Queen Charlotte Islands), a forest company managed by the Council of the Haida Nation (Taan Forest) manages 193,000 ha under a special land use order with similar provisions to EBM in the Great Bear Rainforest (Province of BC 2014). The Tree Farm Licence managed by Taan Forest is certified by the Forest Stewardship Council. The FSC certification is in partnership with BC Timber Sales and includes adaptive management strategies with monitoring of stand-level biodiversity indicators. Between 2011 and 2017, 3092 ha were harvested using VR (Taan Forest 2018).

\section{Adaptive management and monitoring}

In this section, we review the major adaptive management (AM) and monitoring initiatives underway in $\mathrm{BC}$ to evaluate the outcomes of VR and other practices associated with ecologically based management. Many of the $\mathrm{BC}$ studies reviewed in this paper section four arise from these programs.

\section{The Forest Project/Coast Forest Strategy}

The 'Forest Project' was a multi-faceted initiative by MacMillan Bloedel, created in response to the issues of clearcutting and old-growth conservation (Coady 2000). The project included ecological, economic and social components designed to create a 'social license' to operate with a largely old-growth timber supply. The ecological component addressed public concerns about clearcutting, old-growth and biodiversity conservation by adopting variable retention, reserving more old-growth using a landscape zoning scheme and designing an adaptive management program (Bunnell and Dunsworth 2009). Before 1998, the variable retention approach had never been attempted in $\mathrm{BC}$ on an industrial scale and as such was a grand experiment. The adoption of VR within a 5-year phase-in period required rapid adjustments in planning, harvest operations and silviculture practices. A primary objective was to sustain biological diversity throughout the company's private and public lands. An estimated 175 native terrestrial vertebrates potentially breed on these lands, plus an unknown number of other organisms (Bunnell et al. 1998). Retention of these organisms, while harvesting the wide range of tree species, is the ultimate test of the goal to sustain biodiversity. The Forest Project team recognized that the novel approach required AM, including a cost-effective monitoring program. AM is a structured approach to learning from operational practices, monitoring and experiments to provide feedback to management and continual improvement (Holling 1978).

The strategy for maintaining biological diversity included two key elements: variable retention and landscape zoning. Stewardship zones varied in harvesting intensity and landscape-level reserves. The AM framework was structured with a criterion and indicators (Bunnell and Dunsworth 2009). The criterion was 'biodiversity is sustained within the 1.1 million ha coastal forest tenure'. The indicators of success were:

1. Representation. Ecologically distinct ecosystem types are represented in the non-harvestable land base of the tenure to maintain lesser known species and ecological functions.

2. Structure. The amount, distribution and heterogeneity of stand and forest structures important to sustaining native species richness are maintained over time.

3. Species. The abundance, distribution and reproductive success of native species are not substantially reduced by forest practices.

The focus of the AM program was structured learning-answering key strategic and tactical questions. Learning was primarily through operational and experimental comparisons that informed the key questions, as described in detail by Bunnell and Dunsworth (2009). Although the AM program included monitoring of operational sites, experimental sites were established to facilitate quicker learning and to provide a series of comparisons with greater control of confounding variables. The experiments are known as the Variable Retention Adaptive Management (VRAM) sites (Beese et al. 2005).

The experimental design for the VRAM areas consists of three replicates for each of five comparisons 
(Additional file 1: Figure A1). Each VRAM site consists of four or five treatments, each applied to a 20 ha area: two or three VR options, plus clearcut and uncut areas. Each VRAM site requires an area of 80 to 100 ha that is as uniform as possible in timber type, plant associations and topographic features. Treatments were randomly allocated to blocks before field layout. Nine of the 15 planned VRAM sites were completed by 2005 ; three compare group (aggregate) retention percentage (Goat Island, Hoodoo, Tsitika), two compare group size (Cluxewe, Klanawa), two compare riparian retention (Lewis Lake, Moakwa), one compares dispersed retention percentage (Horseshoe Lake, Fig. 3) and one compares the size and timing of group removal (Memekay); see Additional file 1: Table A1. Due to company ownership changes and economic conditions, no further VRAM sites have been established. Company biologists collaborated with academic and government scientists to support research, and a group of international scientists provided advice on the AM program implementation. Forestry and Biodiversity (Bunnell and Dunsworth 2009) provides a comprehensive description of this case study.

\section{The Forest Strategy-ongoing implementation by Western Forest Products Inc.}

The original Forest Project/Coast Forest Strategy zoning scheme was modified after company mergers substantially changed the land base, now managed by Western Forest Products Inc. (Western). The basic principles applied to zoning were (1) to have a range of emphases on timber production and biodiversity conservation across the zones and (2) to use ecosystem characteristics to guide objectives and practices. The zones use broad ecological units (ecosections), landscape objectives under the Vancouver Island Land Use Plan (BC Integrated Land Management Bureau 2000) and biogeoclimatic subzones (Klinka et al. 1991) as a basis for assigning different proportions of the retention system and minimum levels of retention by zone. Landscapes with high windthrow hazard and a timber production emphasis have a target of $10 \%$ stand-level retention with at least $30 \%$ of harvesting meeting the retention system definition. In contrast, landscapes with low windthrow hazard, low levels of landscape reserves due to a long history of development and a high biodiversity value have targets of $20 \%$ stand-level retention and at least $70 \%$ use of the retention system. Western's Forest Stewardship Zones combine elements of different approaches implemented by predecessor companies (Deal 2005; Bunnell and Dunsworth 2009). They are also similar in concept to the 'TRIAD' zoning approach (Hunter and Calhoun 1996), whereby a forest area is divided into three zones with varying emphasis on conservation and intensive management. TRIAD zoning is growing in popularity within Canada as a means of fulfilling diverse objectives (Côté et al. 2010; MacLean et al. 2008; Montigny and MacLean 2006).

Western monitors the achievement of targets for the percentage of harvest area completed using the retention system and the stand-level retention percentage for each of the Forest Stewardship Zones. Results are evaluated annually based on a 5-year rolling average. For 2014-2018, the company exceeded both targets for all zones. Percent

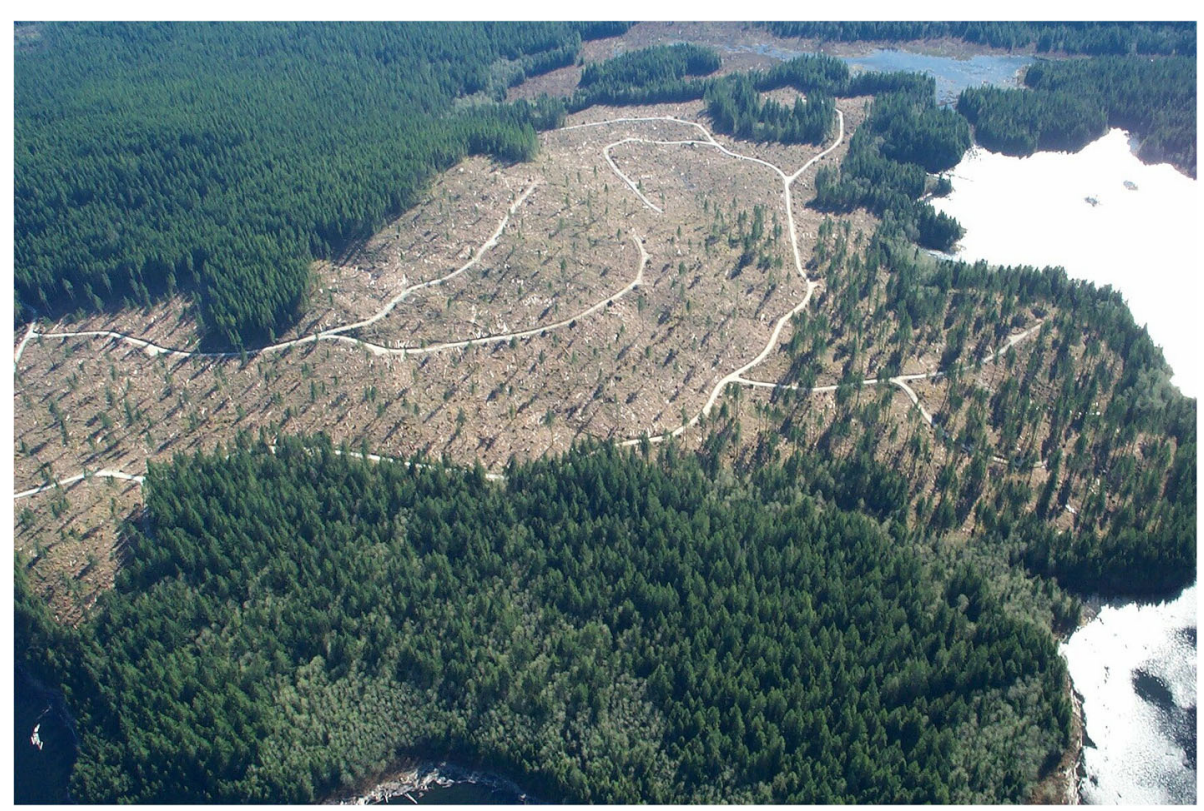

Fig. 3 VRAM dispersed retention experiment at Horseshoe Lake near Powell River, BC. Treatments are uncut (lower), clearcut (upper center) and 10\%, 5\%, 30\% retention (left to right, middle). Photo by W.J. Beese 
retention system targets were exceeded by $5 \%$ to $17 \%$ among zones. Average stand-level retention for zones ranged from 27 to $33 \%$ against targets of $10 \%$ to $20 \%$. Implementation monitoring is carried out on a 5-year interval unless a change occurs which warrants a more frequent sampling. The purpose of implementation monitoring, using random field checks, is to ensure the intent of retention is being met. A LiDAR-based tool has been developed to calculate the percent forest influence for each cutblock (i.e. the area within one tree length of a timber edge)-a key 'rule of thumb' metric for the retention system.

\section{Other special land use plans in BC}

Other AM and monitoring initiatives in coastal BC include the Clayoquot Sound region, managed under the Clayoquot Scientific Panel recommendations (CSP 1995), the Great Bear Rainforest managed under ecosystembased management guidelines (Price et al. 2009) and Taan Forest in Haida Gwaii. Forests in Clayoquot have been managed by First Nations owned forest companies (Iisaak Forest Resources Ltd., MaMook Natural Resources Limited) created after the CSP. Monitoring activities have included windthrow and residual stand damage, and the distribution and abundance of wildlife trees, coarse woody debris and native plants; unfortunately, monitoring has been very limited (Bunsha 2012). Through the Coastal Stewardship Network, First Nations in the Great Bear Rainforest are engaged in collaborative monitoring activities using traditional Nation-based Guardian Watchman programs (Coast Funds 2019). A regional monitoring strategy was developed to collect standardized field data that feeds into a database for the entire land use plan area, largely focused on the marine environment and stream habitat. Taan Forest and BC Timber Sales have a monitoring program supporting FSC certification in Haida Gwaii. Stand-level biodiversity indicators include attributes such as retention level, retention patch size and coarse woody debris.

\section{Forest and Range Evaluation Program}

The Forest and Range Evaluation Program (FREP) monitors forest practices in $\mathrm{BC}$ under the Forest and Range Practices Act (BC-FRPA 2002). There are 11 resource values (e.g. biodiversity, cultural heritage, recreation, soils, timber, visual quality, water) identified under FRPA, and FREP has the responsibility for implementation and effectiveness monitoring for these values. FREP is a foundational element of the results-based approach in FRPA by providing science-based evidence to guide continual improvement of practices, policies and legislation (FREP 2016). Monitoring protocols have been developed for most resource values, including stand-level biodiversity. Field data are collected by government field staff from randomly selected, recently harvested cutblocks. Data includes the quality and quantity of tree retention and coarse woody debris.

\section{Review of key findings from monitoring and research}

Research and monitoring of indicator (focal) species are used to assess whether or not strategies for leaving representative unmanaged areas and habitat structures actually result in viable populations of forest-dwelling species. Informative focal species are forest-dwelling, sensitive to forest practices, practical to monitor and provide information that can guide management (Bunnell and Dunsworth 2004, 2009). A review of the biodiversity aspects of retention from 214 studies found beneficial effects of tree retention on species diversity compared to clearcutting (Rosenvald and Lõhmus 2008). A growing number of studies are documenting significant benefits of the VR approach (e.g. Baker et al. 2013, 2015). A metaanalysis of 78 studies comparing retention harvests with clearcuts found that retention cutblocks supported higher richness and a greater abundance of forest species than clearcuts (Fedrowitz et al. 2014); however, retention cutting had negative impacts on some species compared to uncut forest. Here, we review key findings from studies in $\mathrm{BC}$ and adjacent US states, including some as yet unpublished results from the VRAM experiments. Unless otherwise noted, percent retention refers to area when referring to aggregated (group) retention and basal area when referring to dispersed (single tree) retention.

\section{Structural retention and habitat attributes}

Monitoring of VRAM sites and operational cutblocks by Western and predecessor companies have documented the structural attributes (i.e. biological legacies and specific habitat elements) provided by retention in relation to benchmark natural forests in coastal BC. Long-term retention in operational cutblocks (reported annually and verified with a random sample) averaged over 20\%, primarily designed as aggregated or mixed retention (Beese et al. 2003). Stand-level retention ranged from 5 to $55 \%$ during VR phase-in, with almost $75 \%$ of cutblocks in the 11-30\% range (Bunnell and Dunsworth 2009). From 1999 to 2005, transects were established to monitor retained vegetation structure in 193 VR blocks, 98 uncut sites and 52 other sites (Huggard et al. 2009b). Measured structural elements included live trees; snags (dead standing trees) and coarse woody debris (species, diameter, height and decay class); cover layers (canopy, small tree, shrub, herb, moss, litter and mineral soil); and dominant shrub and herb species (Huggard et al. 2009a; see Additional file 1: Appendix B for methodology). Detailed analyses examined 63 different habitat elements. Initial comparisons assessed whether retention patches provide 
similar levels of attributes to those found in unlogged (benchmark) forests. Overall, retention tended to have lower levels of some important elements, especially large trees, total basal area and some vegetation layers, compared to benchmark sites in the same biogeoclimatic unit (Huggard et al. 2009b). Snag density was lower for benchmark sites than retention patches in drier biogeoclimatic subzones, but higher for benchmark sites than retention patches in wetter subzones. In some areas, tall snags were less common in retention patches, especially near the edges, because of removal of hazard trees during harvesting. The abundance of live and dead tree habitat elements was proportional to percent retention for aggregated retention, which had higher amounts of many elements compared to dispersed retention (Huggard et al. 2009b). Cutblocks were resampled to assess five-year post-harvest changes. Standing tree density in retention declined about $20 \%$ over 5 years due to windthrow and other mortality. Both growth and mortality rates of trees were higher on the edges of retention patches, mostly within $10 \mathrm{~m}$ of the edge, with some effects up to $20 \mathrm{~m}$ into the patch. Other than for small trees, tree mortality was similar in dispersed and aggregated retention (Huggard 2005, 2006). Postharvest structure sampling was completed for two VRAM experimental sites in 2006, representing different amounts of dispersed (Lois/Horseshoe Lake) and aggregated (Tsitika) retention (Additional file 1: Table B2).

Densmore (2011) completed a detailed analysis of FREP stand-level biodiversity monitoring on over 400 cutblocks from 2006 to 2009 for the major biogeoclimatic subzones of the $\mathrm{BC}$ coast. Average retention was $22.8 \%$ of the total gross area of the sampled cutblocks. Quality of retention, as measured by large snags, large live trees and number of tree species, was consistently high for all but one of the six subzones. The volume of coarse woody debris in harvested areas was equal or greater to baseline amounts in retained patches; however, piece size was lower than the baseline for half of the subzones.

For the South Coast and West Coast Regions, FREP monitoring of cutblocks harvested from 2007 to 2014 found that $94-97 \%$ met the $3.5 \%$ minimum retention level with average retention over $20 \%$ and $17 \%$, respectively. Density of large diameter live and dead trees in retention was typically below baseline levels for wetter biogeoclimatic subzones but similar to unlogged baseline data for drier subzones on the mainland coast. The volume of coarse woody debris on cutblocks was similar or somewhat higher than the baseline for most subzones, although the contribution of large diameter stems was somewhat lower in some units (FREP 2016).

In Haida Gwaii, results from FREP monitoring of Taan Forest for 33 cutblocks between 2006 and 2010 showed an average of $13 \%$ stand-level retention; this increased to
27\% for ten cutblocks assessed between 2011 and 2015, and 34\% for 2016 (Taan Forest 2018). Other indicators of stand-level biodiversity that were monitored but are not reported here are average patch size, the amount of large snags and coarse woody debris relative to natural benchmarks and percent windthrow.

In neighboring Washington and Oregon, the Demonstration of Ecosystem Management Options (DEMO) study characterized structural differences among variable retention treatments and found that they were highly influenced by initial stand conditions (Maguire et al. 2007). Dispersed treatments maintained significantly greater canopy cover than aggregated treatments at the same retention level. A retrospective study of structural attributes retained by partial cutting over the past century in southeast Alaska found that a tree species composition similar to that in uncut old-growth stands was maintained (Deal and Tappeiner 2002). It is easier to maintain a range of stand attributes more similar to pre-harvest conditions using aggregated retention than with dispersed retention.

\section{Wind damage to retention and cutblock edges}

Wind damage has the potential to significantly alter stand structure in the initial years following variable retention harvesting. The maritime, hypermaritime and montane rainforest ecosystems of coastal Washington, $\mathrm{BC}$ and Alaska experience a strongly seasonal climate with mild, dry summers and wet windy winters. Largescale counter-clockwise-rotating extratropical cyclones which form over the Pacific Ocean produce strong southerly winds as they reach the coast, and northwest winds as they cross inland. Orographic effects lead to very heavy precipitation as these systems cross the coastal mountain ranges. Wind damage from uprooting (windthrow) and breakage of trees is a major and recurrent natural disturbance process in coastal rainforests, ranging from individual tree to whole-stand replacement (Mitchell 2013). Nowacki and Kramer (1998) describe recurrent storm-induced whole stand replacement in coastal Alaska, which leads to distinctive soil chemistry and microtopography (Bormann et al. 1995; Kramer et al. 2001, 2004; Leckie et al. 2004).

Trees which are abruptly exposed by harvesting of adjacent trees are vulnerable to damage from annual winter storms, and monitoring of operational cutblocks and VR trials reveals the impact of harvest intensity and arrangement (Table 1). Across these studies, windthrow ranges from 2 to $53 \%$ of retained trees. Damage increases as harvesting intensity increases, and is higher in smaller aggregates than in larger ones. Wind damage varies regionally, with high rates of loss in Haida Gwaii and the exposed west coast of Vancouver Island (Beese et al. 2019) and lower rates in the more sheltered inland biogeoclimatic zones (Steventon 2011). Local variation in stand 
Table 1 Windthrow in variable retention trials and operational cutblocks in British Columbia

\begin{tabular}{|c|c|c|c|c|c|}
\hline Study name & Ecological conditions $^{a}$ & Retention type & Years $^{b}$ & Wind damage ${ }^{c}$ & Citation \\
\hline $\begin{array}{l}\text { Operational VR, Clayoquot } \\
\text { Sound, BC }\end{array}$ & $\begin{array}{l}\text { Hypermaritime } \\
\mathrm{CWH}\end{array}$ & $\begin{array}{l}\text { Dispersed, } \\
\text { Aggregated, } \\
\text { Mixed }\end{array}$ & $1-6$ & $\begin{array}{l}16.5 \% \text { of } 1215 \text { stems in various types } \\
\text { Increased with percent of trees harvested; } \\
\text { Dispersed }>\text { Aggregated }\end{array}$ & Scott and Mitchell 2005 \\
\hline $\begin{array}{l}\text { STEMS 2- Campbell } \\
\text { River, BC }\end{array}$ & $\begin{array}{l}\text { Very Dry } \\
\text { Maritime CWH }\end{array}$ & $\begin{array}{l}\text { Dispersed, } \\
\text { Aggregated, } \\
\text { Other systems }\end{array}$ & 2 & $\begin{array}{l}\text { Dispersed } 40 \text { stems/ha (5\%): } 24 \% \\
\text { Small aggregates (0.05 ha): } 54 \% \\
\text { Thinning ( } 64 \% \text { volume removed): } 18 \% \\
\text { Group selection ( } 25 \% \text { removed): } 5 \% \\
\text { Patch cuts ( } 25 \% \text { removed): } 6 \% \\
\text { Control (unharvested): } 8 \% \\
\text { Aggregated > Dispersed }\end{array}$ & $\begin{array}{l}\text { deMontigny and } \\
\text { Nigh 2009, Byrne } \\
\text { and Mitchell } 2013\end{array}$ \\
\hline $\begin{array}{l}\text { MASS_Campbell } \\
\text { River, BC }\end{array}$ & Montane CWH & $\begin{array}{l}\text { Dispersed, } \\
\text { Aggregated } \\
\text { Shelterwood }\end{array}$ & 6 & $\begin{array}{l}\text { Dispersed } 25 \text { stems/ha: } 29 \% \\
\text { Large aggregates ( } 1.5 \text { ha): } 2 \% \\
\text { Shelterwood ( } 25 \% \text { basal area retained): 10\% } \\
\text { Dispersed > Aggregated }\end{array}$ & Beese 2001 \\
\hline $\begin{array}{l}\text { Operational VR_Kispiox } \\
\text { Forest District, BC }\end{array}$ & $\begin{array}{l}\text { Moist Cold ICH } \\
\text { Wet Submaritime } \\
\text { Montane CWH }\end{array}$ & Aggregated & $12-16$ & $\begin{array}{l}\text { Aggregates ( } 0.8 \text { ha avg.): } 9 \% \\
\text { Less windthrow in larger aggregates }\end{array}$ & Steventon 2011 \\
\hline $\begin{array}{l}\text { Operational VR, } \\
\text { Weyerhaeuser/Western, } \\
\text { AM Monitoring, Coastal BC }\end{array}$ & $\begin{array}{l}\text { Hypermaritime, } \\
\text { Maritime, } \\
\text { Montane CWH }\end{array}$ & $\begin{array}{l}\text { Aggregated, } \\
\text { Mixed }\end{array}$ & $2-5$ & $\begin{array}{l}\text { Small to medium aggregates } \\
\text { (0.22 ha avg.): } 37 \% \text { ( } 23-53 \%) \\
\text { Large aggregates (> } 1 \text { ha): } 24 \% \text { (16-45\%) } \\
\text { Less windthrow in larger aggregates }\end{array}$ & Beese et al. 2019 \\
\hline
\end{tabular}

${ }^{a}$ Biogeoclimatic zones and subzones: CWH Coastal Western Hemlock zone, ICH Interior Cedar Hemlock zone; subzone names from Klinka et al. (1991); all areas are coastal except the ICH portion of Steventon (2011), which has forests similar to the CWH zone; other interior sites (Bulkley/Morice) in Steventon not shown ${ }^{b}$ Years post-harvest when wind damage was assessed

${ }^{c}$ Percent damage to retained stems within plots, entire aggregates or a defined strip along larger aggregates; percentages show the average and (range) among study areas or treatments for the cited studies

and site conditions also influence damage rates. In Clayoquot Sound, Scott and Mitchell (2005) reported that the likelihood of being windthrown increased with mean annual wind speed and soil conditions. Windthrow decreased with greater depth of permeable soil, and was lower on mineral soil than on organic soil. There were no differences in windthrow levels between uniform or multi-storied stands. Trees with small live crown ratios and greater slenderness were more vulnerable to damage. The latter result was also found by Byrne and Mitchell (2013) in the uniform Douglas-fir dominated second growth stands at the Silvicultural Treatments for Ecosystem Management in the Sayward (STEMS 2) trial near Campbell River BC (Montigny and Nigh 2009). Damage can continue for a number of years following harvest. In the Montane Alternative Silvicultural Systems (MASS) project on east-central Vancouver Island, Beese (2001) observed that a high wind event 7 years following harvest caused substantial damage to the patches and clear-cut edges.

Beese et al. (2019) conducted windthrow monitoring of 172 VR cutblocks occurred throughout Western Forest Products' BC coastal operations over a 6-year period from southern Vancouver Island (VI) to Haida Gwaii (Queen Charlotte Islands). They found that windward-facing cutblock edges were more vulnerable to windthrow than other boundary exposures and damage differed significantly among biogeoclimatic subzones. Topographically exposed locations such as ridge crests and upper slopes experienced more wind damage than middle and lower slopes. The amount of wind damage also increased with increasing stand height and fetch distance. Contrary to many studies, windthrow increased with soil depth-a finding the authors attributed to stand height superseding soil factors as a causal agent for windthrow over a broad landscape. The distance that windthrow penetrated a stand edge was affected by some of the same factors as percent damage. Penetration along cutblock edges varied regionally from 6 to $20 \mathrm{~m}$. The results suggest that designing variable retention for local site, stand and wind exposure conditions can reduce the potential for wind damage.

\section{Effects on tree growth and understory vegetation}

The greatest impacts on early growth of residual trees are from mortality due to wind damage and from wounding during harvesting. Impacts from both sources are typically greater for dispersed retention than for aggregated retention or group removal (Phillips 1996; Aubry et al. 2004). Studies in southeast Alaska found that dispersed retention resulted in greater tree wounding during timber harvesting than aggregated retention or group selection (McClellan and Hennon 2005); however, a decay projection model estimated that volume losses at the end of an 80-year rotation would be minimal (Hennon and DeMars 1997). Wind damage has more significant impacts on residual trees in coastal BC than tree wounding during harvesting.

The main silvicultural concern about variable retention is the potential impact on future stand growth. Permanent 
plots were established on VRAM sites and supplemental areas to measure the impact of the amount and spatial distribution of retention on tree growth. An innovative 'sector' sampling scheme was developed in order to obtain a proportional sample of retained aggregates and surrounding cut areas (Iles and Smith 2006). A model was developed (N.J. Smith, pers. com.) that tracks growing season light and moisture to predict growth for western hemlock and Douglas-fir. Findings to date suggest that most of the impact of aggregated retention on growth of regenerating trees is restricted to $10 \mathrm{~m}$ from the stand edge into the opening. Growth was highly correlated with surficial moisture, suggesting that the impact of residual trees on regeneration is due to moisture competition rather than shading. For a given retention level, as measured by percent canopy, growth impacts on regeneration were greater for dispersed retention than aggregated retention (N. J. Smith, unpublished data). For the VRAM dispersed retention comparison, Douglasfir basal diameter growth was reduced 5 to 6 years after planting under $30 \%$ dispersed retention compared to a clearcut, but not for 5-15\% dispersed retention (Smith and Beese 2012).

Ten-year results from planted regeneration studies at the MASS study in coastal BC found reduced growth compared to clearcutting for amabilis fir and western hemlock in a shelterwood with $25 \%$ residual basal area, but little impact on growth for 5\% dispersed retention and 1.5 ha patch cut treatments (Mitchell et al. 2007). Growth rates of regeneration 10 years after single tree and group selection in western hemlock-amabilis fir oldgrowth stand on the west coast of Vancouver Island were greater for group selection than single tree selection, where initial volume removal was $25 \%$ for both systems (D'Anjou 2003). At the DEMO sites in Washington and Oregon, a study comparing the effects of different levels and patterns of retention on planted and naturally regenerating conifers found that after 12 years dispersed retention reduced growth of planted Douglas-fir and other species more than aggregated retention for a given retention level, and dispersed treatments had greater density of natural regeneration (Urgenson et al. 2013). Examining edge effects at DEMO after 20 years, Whyte and Halpern (2019) found that density of natural conifer regeneration increased with closer proximity to the edge of aggregates and unharvested forest edges, but height tended to decrease closer to edges, although there was variation in response among conifer species and age of regeneration.

Monitoring of VRAM sites and operational cutblocks documented changes to understory vegetation 5 years after harvesting (Huggard 2005, 2006). Attributes measured on transects within dispersed retention areas, up to $50 \mathrm{~m}$ into retained aggregates and $50 \mathrm{~m}$ into adjacent cut areas included height and cover of dominant shrubs, herbs and moss (Additional file 1: Appendix B, Figure B1, B2 and Table B1). In general, aggregated retention maintained vegetation elements that were more similar to uncut benchmark sites than did dispersed retention. Edge effects on herb and shrub layers within aggregates and adjacent cut areas were minor, and were concentrated within $10 \mathrm{~m}$ of the stand edge. Shrub cover in cut areas, with or without dispersed retention, was about $70 \%$ less compared to retained aggregates and benchmarks. Herb and moss cover was similar for retention aggregates compared to uncut benchmarks. Herb cover was reduced initially in cut areas and moss was almost eliminated. Dispersed retention, which was practiced primarily in drier biogeoclimatic units (i.e. Coastal Douglas Fir zone; and Coastal Western Hemlock $(\mathrm{CWH})$ zone, very dry maritime, dry maritime and moist maritime subzones; Klinka et al. 1991) generally had higher levels of mineral soil exposure than the cut areas of aggregated retention sites.

Early results from permanent understory vegetation plots at the MASS study near Campbell River found that a shelterwood with $25 \%$ basal area retention had greater post-harvest abundance (frequency per replicate) of understory trees, shrubs and bryophytes compared to a clearcut; patch cut (1.5 ha cut areas) and dispersed retention (5\% basal area) treatments were not significantly different from the clearcut (Beese and Bryant 1999). Richness, diversity (Shannon-Wiener $\mathrm{H}^{\prime}$ ) and evenness did not differ significantly pre- or post-harvest among treatments. A postharvest decline in species associated with undisturbed forests and increase in early seral species was least pronounced in the shelterwood treatment, thereby maintaining the greatest similarity to the old-growth control in terms of overall species and life-form composition. Species gains exceeded losses on treatment plots; however, bryophytes and herbs (e.g. orchids, lilies) that prefer moist, shaded habitats generally decreased after harvesting. Fifteen-year results from the same study at MASS (Beese et al. 2009, unpublished data $^{2}$ ) showed no significant differences in diversity measures among treatments, but shelterwood, patch cut and dispersed retention treatments had greater diversity at 15 -year post-harvest than preharvest $(p<0.05)$. Retention studies in many forest types report increased species richness or diversity after harvesting from and influx of early-seral species in cut areas plus species maintained from the pre-harvest stand (e.g. Halpern et al. 2012; Roberts et al. 2016; Lilles et al. 2018), but not in all cases (Craig and Macdonald 2009).

Of the primary issues associated with biodiversity and forest harvesting, of greater concern than overall diversity is the impact on species associated with older forests. Herbs whose presence decreased with disturbance at MASS were mostly Orchidaceae (Platanthera dilatata, Listera caurina) and Pyrolaceae (Moneses uniflora, Orthilia secunda, Chimaphila menziesii), which prefer moist, 
shaded habitats. At the DEMO study areas in Oregon and Washington, Halpern et al. (2012) found that late-seral herbs were sensitive to both the amount and pattern (aggregated vs. dispersed) of retention. They observed local extirpation of late-seral associated herbs was greatest in the harvested areas between aggregates and at the lowest level of dispersed retention (15\%).

Bryophytes decreased after harvesting at both MASS and DEMO (Halpern et al. 2012). By year 15, several bryophytes that were reduced after harvesting at MASS began to recover. In a BC interior cedar-hemlock forest, Lilles et al. (2018) documented that recovery of non-vascular plants over a 24-year period increased with retention level. The bryophyte study at MASS was limited to about 20 species that occur on forest floor and mineral soil. Much of the diversity in bryophytes, particularly liverworts, is associated with decaying wood and lower tree trunkshabitats that are lost or significantly altered after forest harvesting (Baldwin and Bradfield 2005). Aubry et al. (2009) suggest that retaining trees in 1 ha aggregates can provide short-term refugia for late-seral herbs and bryophytes, but note the susceptibility of aggregates to edge effects. Other studies suggest that fungi and lichens have more species associated with old forests and are of greater concern for losses from harvesting (Sillett et al. 2000; Coxson and Stevenson 2007; Molina et al. 2001; Trofymow et al. 2003).

\section{Effects on birds}

On the $\mathrm{BC}$ coast, aggregated retention was found to be beneficial for bird species typically found in uncut forests, and bird occurrence was positively correlated with percent retention (Preston and Harestad 2007). Overall results to date from bird studies at VRAM sites show that all guilds (groups of species with similar habitat preference) and about one-third of individual bird species were affected by retention level (Chan-McLeod 2008). Mature-forest dwelling species were generally more abundant at higher VRAM retention levels compared to $10 \%$ retention or clearcuts. Removal of $31 \%$ of the original forest in various aggregate sizes (69\% retention, at Memekay VRAM) had little impact on forest bird communities. Dispersed retention levels of $5 \%$ to $10 \%$ showed no significant overall difference in bird abundance from clearcuts, which favored shrub nesters and 'open' habitat species. Aggregate size appeared to have an impact on some species, with large aggregates (1 ha) preferred over small- to medium-size aggregates ( 0.25 to $0.5 \mathrm{ha}$ ), although results with retention type and level were highly variable. In Australia, a study designed to test the impact of aggregate size on birds found no significant size effects on bird species richness when comparing retention of three 0.5 ha aggregates to one 1.5 ha aggregate (Lindenmayer et al. 2015).
Huggard and Bunnell (2007, extension brochure ${ }^{3}$ ) examined study results for 69 species of birds and concluded that many less-sensitive species decreased substantially below $15 \%$ to $20 \%$ retention, and some sensitive species declined more abruptly below $35 \%$ to $40 \%$ retention. A meta-analysis of studies comparing green tree retention levels up to $50 \%$ did not demonstrate statistical differences in species richness and abundance for a variety of taxa among four classes of retention level because of high variability (Rosenvald and Lõhmus 2008); however, this review found a positive relationship between persistence of several species groups and tree density in about twothirds of the relevant studies and retention pattern in half of the studies. Fedrowitz et al. (2014) found that pattern of retention (dispersed vs. aggregated) had no effect on the differences between clearcuts and retention cuts, although they noted that limited data was a factor in their analysis. A recent meta-analysis of 30 studies on the response of bird guilds to retention (Basile et al. 2019) found no differences in overall species richness and abundance between retention and uncut forest; however, for forest specialist birds, their findings suggest that $40-60 \%$ retention may be needed to maintain the same bird assemblage found in unharvested forests.

In southeast Alaska, DellaSala et al. (1996) studied forest bird response to treatment of young forests (thinning and gap creation) and compared bird abundance in young forests to old-growth. Although the study did not examine variable retention, the findings are relevant. They recommended leaving patches of old forest during harvesting to enhance habitat of breeding and wintering birds associated with old-growth. Three of 16 common breeding birds were more abundant in old-growth than in treated or untreated young forests: Red-breasted Sapsucker, Pacificslope Flycatcher and Golden-crowned Kinglet. Brown Creeper had a low frequency of detection but was found exclusively in old forests. Higher use of old-growth by wintering birds, such as the Golden-crowned Kinglet, was related to winter severity because of snow interception by old-growth canopies (Kirchoff and Schoen 1987). Similarly, at high elevations on eastern Vancouver Island, Beese and Bryant (1999) found 85\% of winter resident birds in retention aggregates and unharvested old-growth. DellaSala et al. (1996) observed that four bird species were negatively associated with old-growth and others did not differ between young and old forest, which illustrates the fact that not all bird species will benefit from retention. In Washington and Oregon, a study of small passerine birds at the DEMO sites comparing different levels and patterns of retention found that species richness declined significantly 1-3 years after logging for the lowest level (15\%) of both aggregated and dispersed retention (Wilk 2019). Post-harvest Shannon-Weiner diversity was higher for $15 \%$ aggregated vs. dispersed retention. Treatment 
response varied for canopy, cavity-nesting and understory species.

\section{Effects on other vertebrates}

Besides birds, the vertebrates most sensitive to standlevel effects from forest harvesting are small mammals (Bunnell and Dunsworth 2009). Studies of the effect of variable retention on voles in Douglas-fir-lodgepole pine stands in the southern interior of $\mathrm{BC}$ found that retention maintained habitat for southern red-backed voles (Myodes gapperi), a species found in mature and old forest (Sullivan and Sullivan 2011). Aggregated retention maintained red-backed vole populations similar to uncut forest 20 years after harvesting, but dispersed retention did not (Sullivan and Sullivan 2018). Compared to clearcuts, dispersed retention (73-127 trees/ha of overstory, $>10-20 \mathrm{~m}$ height) did not have significantly lower populations of Microtus spp., a genus of voles responsible for feeding damage on seedlings from elevated populations in herb and shrub dominated habitat after harvesting. Sullivan and Sullivan (2011) suggest that higher levels of retention are needed (i.e. enough to suppress understory vegetation) in order to help reduce outbreaks of small mammal damage to tree regeneration. At the DEMO study sites, Gitzen et al. (2007) found that the similarity in relative abundance of 12 small mammal species between harvested areas and uncut forest decreased with decreasing amounts of retention. Capture rates, however, were similar for both aggregated and dispersed retention, and responses among early- and late-successional species were not always as predicted. For the northern flying squirrel, a study at DEMO found that squirrel numbers were higher for uncut forest and $75 \%$ retention treatments than lower levels of retention (40\% and 15\%), supporting previous studies showing their sensitivity to forest harvesting (Holloway et al. 2012).

The impact of forest harvesting on species that are sensitive to microclimatic changes and are less mobile is an important aspect of biodiversity conservation that was investigated on VRAM sites and operational cutblocks (e.g. amphibians; also carabid beetles and gastropods, see below). Wind (2008) examined the effects of harvesting and buffers on amphibian use of small wetlands. Four amphibian species were found breeding in small ponds: longtoed salamander, rough-skinned newt, Pacific chorus frog and red-legged frog. Two and three years after harvesting, all four species have continued breeding at small wetlands at each site and standing water has persisted longer in the season than before harvesting. Frogs utilized more wetlands for breeding after harvesting than before harvesting. Wetlands with no canopy cover appeared to have a greater influx of breeding post-harvest than wetlands with retention. Based on these findings, a field card for identifying important wetland sites was developed (Wind and Beese
2008). Maguire et al. (2005b) did not find a relationship among four species of salamanders and level and pattern of tree retention at the DEMO study; however, salamander abundance was positively correlated to high levels of coarse woody debris and herbaceous cover.

\section{Effects on invertebrates and below-ground diversity Invertebrates}

Carabid (ground-dwelling) beetles have been widely used as indicators of environmental change due to their rapid response to disturbance and a high degree of habitat specialization (Pearce and Venier 2006). Monitoring of carabid beetle response to variable retention harvesting has occurred in coastal and northern BC. One year after harvest at the Tsitika VRAM site (Additional file 1: Figure A1), aggregated retention maintained carabid beetle communities similar to those found in uncut (old-growth) stands, with community similarity, relative to the uncut condition, increasing with retention level (Additional file 1: Figure C1, from Pearsall 2008, unpublished data $\left.^{4}\right)$. This pattern also developed shortly after harvest in aggregated retention sites in Picea engelmannii $\mathrm{x}$ glauca-Abies lasiocarpa forests in northern BC near Smithers (Lemieux and Lindgren 2004). At Tsitika, these patterns were largely driven by the loss of the forest specialist Scaphinotus angusticollis with increased tree removal. However, 6 years after harvest, carabid community diversity metrics were similar across clearcut, aggregated retention and old-growth sampling locations, and lower overall distances in cluster analysis indicated similar community structure among treatments (Additional file 1: Figure C1). Thus, carabid communities at this site appeared to recover regardless of retention level, though the loss of Zacotus matthewsii, an oldgrowth specialist, was noted at all treatments (Pearsall 2008, unpublished data ${ }^{4}$ ).

Some inconsistencies in the effects of variable retention harvesting on carabid populations were found at some VRAM sites, most likely attributable to site differences and post-harvest windthrow. Four years after harvest at a VRAM aggregated retention site (Goat Island), the 10\% retention area showed high carabid community similarity to the uncut second growth control, whereas the $20 \%$ and $30 \%$ retention areas (which experienced high levels of windthrow damage) had carabid communities more similar to the clearcut. Despite this, carabid beetle samples collected within or at the edge of retention patches clustered together and separately from the cut matrix samples, suggesting that aggregates maintained carabid communities distinct from those found in cut areas (Additional file 1: Figure C2, Pearsall $2009^{5}$ ). Three years after harvest at a riparian aggregated retention VRAM site (Lewis Lake), the samples from the 15\% site showed more similarity to the uncut second growth than the $50 \%$ site, 
which was located on a dry site at the crest of a hill (Additional file 1: Figure C3). At the Moakwa riparian retention VRAM site, both retention levels (15\% and 50\%) were largely unsuccessful at maintaining mature-forest carabids (Additional file 1: Figure C4). Importantly, the old-growth control stand at Moakwa had high abundance of oldgrowth specialists Z. matthewsii, Scaphinotus johnsoni and other forest specialists, which may have driven site separation between cut areas and the uncut stand. Despite the limited efficacy of retention patches at Moakwa for maintaining mature forest carabids, there was evidence of life-boating at this site; the forest specialist $S$. angusticollis was more abundant in the cut areas of retention treatments relative to the clearcut treatment (Pearsall and Beese 2009).

The effect of aggregate size on carabid beetles was investigated on operational cutblocks and on two VRAM group size comparison sites on western (Klanawa, SW of Pt. Alberni) and northern (Cluxewe, near Pt. McNeill) Vancouver Island from 1 to 6 years post-harvest (Pearsall 2007). For both old-growth and second-growth forests, there were higher total catches per trap of forest specialist carabids in larger aggregates $(0.8-1.4 \mathrm{ha})$ than in smaller aggregates (0.1-0.4 ha). Old-growth retention aggregates were generally successful at retaining forest specialists, while small second-growth aggregates were very poor at retaining species such as Pterostichus crenicollis, S. angusticollis and Z. matthewsii. Species-aggregate area curves for these three forest specialists showed a positive response to aggregate size for $P$. crenicollis and S. angusticollis, but not Z. matthewsii (Additional file 1: Figure C6, C7 and C8, from Pearsall 2007).

While aggregated retention has shown varied success for carabid beetles, monitoring of dispersed retention sites in coastal BC has demonstrated this method of harvesting may be unsuitable for retention of carabid beetles. At a dispersed retention VRAM site (Fig. 3, Additional file 1: Figure A1), clearcut and dispersed retention treatments shared a similar carabid community composition 1 year after harvest, with abundance declining in these treatments, but not in uncut stands, 6 years after harvest (Additional file 1: Figure C5, Pearsall 2008, unpublished data ${ }^{4}$ ).

Gastropods are particularly sensitive to harvest due to their limited dispersal ability and strict moisture requirements. The response of gastropods to VR harvesting was assessed at six VRAM sites (Ovaska et al. 2016). The abundance of Pristoloma species, small snails (as a group), Haplotrema vancouverense and Striatura pugetensis was lower in all harvesting treatments after 2 to 4 years, relative to pre-harvest and uncut controls at four VRAM sites with varying levels of retained aggregates, showing no benefit over clearcutting. Similarly, at the site shown in Fig. 3, the three levels of dispersed retention reduced the abundance of five gastropods and all small snails relative to the control. However, the highest dispersed retention level (30\%) showed higher abundance of some species (Planigyra clappi, Vertigo species and Vespericola columbianus) relative to the other harvested treatments. At a VRAM aggregate size comparison, the large aggregatesize treatment supported high abundances of Pristiloma species, S. pugetensis, and small snails combined, and had overall higher gastropod richness relative to the smallersized aggregates and the clearcut treatment (in most cases). Overall, larger aggregates ( $>0.8 \mathrm{ha})$ anchored on riparian areas and high levels of dispersed retention (30\%) are recommended for improved conservation of gastropods.

\section{Soil biodiversity}

Aggregated and dispersed retention harvesting has successfully maintained fungal communities, especially rootassociated ectomycorrhizal fungi, at several sites in coastal BC. At two sites on Vancouver Island, Outerbridge and Trofymow (2004) found increased ectomycorrhizal diversity and percent root colonization on the roots of planted Douglas-fir seedlings with increasing proximity to retention patches. At the dispersed retention VRAM site (Fig. 3), using comparable methodology, Outerbridge and Trofymow (2009) found similar trends; they also concluded that increased retention levels had improved outcomes for ectomycorrhizal diversity. A multidisciplinary group of studies is examining soil microbial and faunal diversity and function in response to a wide range of silvicultural systems (Table 1; www.for.gov.bc.ca/hre/stems) at the STEMS research site on Vancouver Island (Grayston et al. 2005). At STEMS2, Jones et al. (2008) found no differences in ectomycorrhizal fungal communities between uncut stands and a range of aggregate sizes (5-40 $\mathrm{m}$ in diameter), 4-6 months after harvest, but the influence of the patch in maintaining ectomycorrhizal diversity disappeared $10 \mathrm{~m}$ from the patch edge. However, 10 years after harvest at the STEMS1 research sites, Kranabetter et al. (2013) found reduced abundance and fruiting of ectomycorrhizal fungi in patch sizes $<20 \mathrm{~m}$ in diameter relative to uncut stands. These authors noted that although none of the patch sizes successfully maintained ectomycorrhizal diversity relative to continuous forest, the reductions in diversity were modest and populations of prominent fungi were stabilized in patch sizes of at least 0.2 ha. When considering all fungal guilds in decomposing fine roots, Philpott et al. (2018) found that 6 years after harvest at STEMS3, aggregated retention maintained fungal communities similar to those found in uncut stands, whereas fungal communities in the dispersed retention treatment were more similar to those found in the clearcut. However, rapid post-harvest recovery occurred regardless of harvest method at the STEMS1 site, where fungal community composition did not differ among retention, clearcut and uncut treatments 13 years after harvest. 
The ability of variable retention harvesting to maintain overall belowground biodiversity has also been assessed at STEMS1 and STEMS3 using phospholipid fatty acid analysis (PLFA), a broad-scale microbial community profiling technique. Five years after harvest at STEMS 1, Dewi (2009) found increased abundance of fungal biomarkers in the forest floor of retention patches and in the dispersed retention treatment relative to the clearcut treatment. Fungal biomarkers declined with distance from aggregates, whereas microbial community structure was maintained evenly across the cutblock in the dispersed retention treatment. This same trend was also observed for total microbial biomass. Two years after harvest at STEMS3, Churchland (2013) found reductions in fungal biomarkers in the cut matrix surrounding retention patches, and in the dispersed retention treatment. Although these results are somewhat contradictory, the additional time since harvest in the Dewi (2009) study may have allowed for sufficient recovery of fungal communities in the dispersed retention treatment. Overall, these results indicate that dispersed retention is more effective at maintaining microbial communities over the entire treatment unit, likely due to overlap in root systems in this treatment, whereas benefits are restricted to within $10 \mathrm{~m}$ of aggregates.

Some benefits of aggregated retention for soil fauna (arthropods) have also been reported at STEMS. One year after harvest at STEMS2, most soil fauna showed no differences in abundance in samples taken from the patch centre, edge or in the cut matrix, but pauropods and soil mites declined with distance from retention patches (Grayston 2007, unpublished data ${ }^{6}$ ). Collembolan communities in samples taken from the centre or the edge of patches were also similar to collembolan communities found pre-harvest. Importantly, most (95\%) of the soil faunal population was found in the forest floor, with soil disturbance (exposed mineral soil) causing significant reductions in the abundance of symphylans, diptera larvae, pseudoscorpions, pauropods and collembola. Thus, aggregated retention likely benefits soil fauna by retaining an undisturbed forest floor, which may serve as refugia after harvest.

\section{Public perception and visual aesthetics}

Social acceptability of harvesting is an important consideration, particularly on public forest lands. Studies of public perceptions of clearcutting, VR and traditional silvicultural systems' effects on scenic beauty or visual quality in Pacific coastal forests show consistent trends. For a given retention level, treatments that leave dispersed individual trees receive consistently higher ratings than aggregated retention (Clausen and Schroeder 2004; Sheppard and Meitner 2005; Ribe 2009). Low levels of retention (under 15\%) of any kind are generally perceived only slightly better than clearcutting.

\section{Conclusions}

\section{What have we learned from variable retention implementation?}

Many factors need to be considered when choosing stand-level practices to meet social, biological and economic goals. The final choice represents a balance among complementary and competing objectives. As such, it is not possible to determine precise and optimal figures for the proportion of different silvicultural systems, the amount of retention in each cutblock or the spatial distribution of retained aggregates or single trees. Nevertheless, such standards must be chosen based on the best available information, theoretical concepts and practical considerations. Experience over the past two decades in coastal $\mathrm{BC}$ suggests the following conclusions that are relevant for applying stand-level retention:

1. The landscape context determines what is necessary or appropriate for stand-level retention in relation to biodiversity conservation goals.

2. It is neither practical, nor likely even possible, to precisely mimic natural disturbance patterns.

3. Riparian networks are a governing factor for retention patterns because of existing reserve requirements and high-value habitat features for many forest organisms.

4. Wind damage is a significant challenge for dispersing stand-level retention, making aggregated retention or clearcutting with reserves the most viable options for some sites in windy landscapes. The potential long-term benefit of retention for enhancing diversity of live trees in future forests may be compromised by wind damage in some locations.

5. Retention provides habitat that allows for some forest-associated organisms to persist after harvesting (i.e. life-boating), with a positive correlation between retention amount and species persistence, greater benefits with aggregates compared to dispersed single trees for some species and some evidence for a positive correlation between aggregate size and species survival.

6. Growth impacts on forest regeneration increase with percent canopy retention, and greater dispersion of single trees or small aggregates.

7. Typical retention levels (under 25\%) do little to distinguish VR from clearcutting in the eyes of the public unless trees are distributed as dispersed individuals or small aggregates.

We also learned a lot about the practical logistics of implementing VR. A preference for aggregated retention over dispersed retention for many habitat values aligns with safety and cost-efficiency (Zielke et al. 2008; Beese 
2013). Aside from the biological benefits of VR, marketplace demands and public perceptions are important influences on forestry practices that make retention a cost of doing business in many areas.

\section{Is variable retention providing benefits for different organisms?}

While VR does not benefit every organism, the studies described above indicate positive effects on many forestdwelling organisms compared to conventional clearcutting. An important caveat on these findings is the relatively short duration of most studies to date, raising the question of whether or not the apparent 'life-boating' effect for some species will persist, or whether or not some differences between regenerating areas of retention blocks and clearcuts will increase or diminish over time.

The follow-up question-'What amount and pattern of retention is appropriate for different species?'-is much more complex. There is no single answer to this question except, when faced with uncertainty, 'don't do the same thing everywhere' (Bunnell et al. 1999). Different species require different habitats, so it is intuitive to keep the retention 'variable'. The amount and pattern of retention should be planned to suit the nature of the ecosystems, the objectives and the species involved.

In general, research results from early post-logging studies suggest that amount of retention is more important than pattern for many species (Maguire et al. 2005a; Fedrowitz et al. 2014). For a given retention level, however, the monitoring and research results described in this paper suggest that leaving aggregates (groups or larger patches of trees) has more ecological value (generally) for a range of organisms than leaving dispersed individual trees; it is also more feasible for forest harvesting. In mountainous areas exposed to severe winds, using clearcuts with adjacent reserves has been successful for reducing wind damage to retention. Monitoring birds, ground beetles, gastropods and other species groups has shown that retention can help many organisms survive and disperse in regrowth stands. There also appears to be a positive correlation between the size of the aggregates and the ecological benefits, but only for some species and ecosystems. While retaining forest that is representative of the original stand is important, exceptions should be made for features of unusual biological significance (e.g. swamps or other wetlands with forested buffers, rare habitat types, snags). For extreme wind-hazard areas, a minimum aggregate size of 1 ha is appropriate. In many stands, the location of riparian habitats, which are typically the most productive in the area, is the primary influence on the final amount and distribution of retention.

In forests where timber production is a major goal, both stand-level retention and landscape-level reserves facilitate biodiversity conservation across the landscape
(Lindenmayer and Franklin 2002). Neither approach alone is likely to be as effective or efficient as the two in combination (Bunnell et al. 1998). An essential element of a broad biodiversity conservation strategy is a network of protected areas and other reserves. The primary function of these landscape-level reserves is to represent the full range of ecosystems within the non-harvestable land base to maintain lesser known species and ecological processes (Kremsater et al. 2003). Variable retention in the harvested 'matrix' between reserves may perform a complementary role for species that do not require forest interior conditions but rely on certain structural attributes. In fact, a fundamental premise of VR is that more species will thrive in the area if mature forest elements are distributed throughout the production-forest landscape rather than adding an equivalent amount of mature forest to the reserve system. For some birds, retaining $15 \%$ to $20 \%$ of the original forest distributed over a cutblock can maintain half the population abundance of the uncut forest condition; however, populations of other bird species decline proportionally or more rapidly as the percentage of suitable habitat is reduced (Huggard and Bunnell $2007^{3}$ ). In other words, the habitat for some species may be improved significantly over a wider area than the sum of the retention area. For other species, adding a large patch to a reserve would have greater benefit than dispersing the equivalent forest area as retention.

The role of VR is particularly important in landscapes that are unlikely to have enough protected areas and reserves to maintain biodiversity on their own. At the other extreme, if a high proportion of a landscape is reserved, then stand-level retention may not be very important. Consequently, the higher the level of landscapelevel reserves, the less important VR or matrix management may be for sustaining viable populations of forest-dwelling species. Furthermore, there are many other factors to consider besides what to reserve from harvesting. Franklin et al. (2018) suggest that intermediate stand treatments to enhance heterogeneity, and recovery periods between regeneration harvests are equally important considerations as retention of biological legacies for an ecological forestry approach. Stand treatments may not be as important in landscapes with a lot of natural heterogeneity (e.g. having a mix of forest ages, productivity classes, wetlands and complex coastline), as is the case in many parts of coastal BC.

Ecosystems can be both resistant and resilient to changes from natural disturbances or cutting (Keenan and Kimmins 1993). Multiple pathways and patterns can occur within the limits of ecosystem processes and the range of natural variation. Therefore, even though emulating nature has emerged as a forest management strategy for sustaining both products and biodiversity, it may not be necessary to attempt to truly mimic natural disturbances. The very nature of commercial forestry (i.e. removal of 
wood) makes precise imitation of natural disturbance impossible (Palik et al. 2002). Unfortunately, past practices on the BC coast have had little regard for natural disturbances. Pearson (2010) estimated that stand-replacing natural disturbances affected $3.1 \%$ of the forested area over the past 140 years on BC's central coast. Although harvesting affected $5.4 \%$ of this same area overall, $59 \%$ of valley bottom areas were harvested, illustrating that both spatial pattern and scale must be considered when assessing the impact of forestry on ecosystems. Observation of the stand structures and patterns of stands across landscapes produced by natural disturbances provides potential models for the desired stand and landscape condition (e.g. Daniels and Gray 2006), but it may not be practical or desirable to emulate the full range of the type, scale and severity of disturbances present. Simplification of natural structures and patterns may be necessary to improve the efficiency of management or to meet other societal objectives (Mitchell and Beese 2002).

\section{Should variable retention be used everywhere?}

$\mathrm{BC}$ has a high diversity of forest ecosystems and disturbance regimes, as well as social and economic considerations that vary from place to place. Forest management practices need to vary in response to this diversity. No single harvesting or silvicultural system is appropriate everywhere. Clearcut, seed tree, retention, shelterwood or selection systems may be ecologically, economically and socially appropriate in the right context. Using a mixture of systems can help achieve a range of patch sizes and structures within stands and across landscapes. Nevertheless, the variable retention approach is intentionally broad enough to encompass a wide range of forest conditions, harvesting systems and regeneration requirements. Forest practitioners must choose the most appropriate silvicultural system, based on safety, ecological and operational factors. Perhaps most importantly, foresters must reconcile or balance the often competing goals of silviculture and biodiversity conservation. While the increase in stand-level retention in $\mathrm{BC}$ over the past 20 years is encouraging, the resistance to adoption of new terminology (i.e. the retention system rather than clearcut with reserves) is disappointing. Use of the retention system in silvicultural prescriptions is currently regional at best, with little use outside of the $\mathrm{BC}$ coast. The commitment in legislation to wildlife tree retention should be supported by silvicultural prescriptions that clearly articulate the long-term intent of such reserve trees.

How can we improve monitoring and adaptive management? It is popular to recommend adaptive management, but does it work in practice? Unfortunately, most examples of applying formal adaptive management in natural resource management have failed because of three main problems:
(1) lack of funding for monitoring, (2) failure of decision makers to embrace the AM concept and (3) lack of leadership to sustain a complex process (paraphrased from Walters 2007). Nevertheless, the Forest Strategy successfully closed the AM loop with changes to stewardship zones and VR guidelines as a result of monitoring (Beese 2013). For example, guidelines for VR were updated to encourage greater use of larger aggregates, and zoning standards for stand-level retention were changed for windthrow-prone areas. Details on AM approaches and the challenges for implementation are discussed for a number of cases in natural resource management (e.g. Stankey et al. 2005; Greig et al. 2013). In the past 20 years, research and monitoring studies have obtained useful results to inform variable retention practices; however, many aspects of biological monitoring require longer time frames for assessment of impacts (Bunnell and Dunsworth 2009). Monitoring species and forest structure are expected to provide data that will help us demonstrate sustainability and biodiversity conservation. Future challenges for forestry in $\mathrm{BC}$ include dealing with the uncertainties of climate change, survival in the world marketplace and our ability to adapt practices to meet changing goals and expectations. Applying adaptive management to these challenges requires a greater long-term funding commitment on the part of government and industry.

Monitoring is an essential part of AM and is composed of three main elements: implementation or performance (have you met the stated targets and standards?), effectiveness (have you achieved the desired outcomes?) and validation (are the assumptions correct?). Validation asks 'why' a practice or strategy is or is not working and also can be considered refinement monitoring or research. Linking monitoring back to management action is fundamental for an effective operational AM program. Unfortunately, much of the current monitoring in $\mathrm{BC}$ is simply implementation monitoring and needs to be refined to adequately address effectiveness and validation. More experimental installations like the VRAM sites are warranted as well as AM comparisons at the watershed scale.

\section{Endnotes}

${ }^{1}$ For posterity, the authors note that Dr. Ken Lertzman (Simon Fraser University), a member of the Clayoquot Scientific Panel, came up with the term "variable retention" that was adopted by the CSP to replace "green tree retention", the term commonly used up to that point. Dr. Steve Mitchell (University of British Columbia) suggested the idea of making a distinction between the variable retention approach, which can be accomplished with modifications to traditional silvicultural systems, and a new "retention silvicultural system" designed specifically to meet the goals of variable retention. 
${ }^{2}$ Beese, WJ, Sandford, JS, Koppenaal, R, Mitchell, AK, Goodmanson, G, Bown, T, Harrison, ML (2009) Conifer growth and understory vegetation response to alternative silvicultural treatments and systems: 15-year results. Final Report, BC Forest Science Program, Project No. Y0911149, 43 p.

${ }^{3}$ Huggard, DJ, Bunnell, FL (2007) Stand-level retention and forest birds: a synthesis of studies. University of BC, Centre for Applied Conservation Research, Forest Sciences Centre, Vancouver, BC (brochure)

${ }^{4}$ Pearsall, IA (2008) Study to assess the efficacy of ground beetles (Coleoptera: Carabidae) as ecological indicators in two variable-retention experimental sites: A temporal comparison. Pearsall Ecological Consulting, Nanaimo, BC. Final Contract Report to Western Forest Products, $166 \mathrm{p}$.

${ }^{5}$ Pearsall, IA (2009) Effect of stand-level structures and configurations on carabid beetles in coastal B.C. VR sites: comparison of riparian retention and group retention VR methods. Final Report, BC Forest Science Program, Project No. Y091065.

${ }^{6}$ Grayston, SJ, (2007) Green tree retention: a tool to maintain ecosystem health and function. Final Technical Report, BC Forest Science Program, Project No. FSP Y073049.

\section{Additional file}

Additional file 1: Supplementary materials, Appendices A - D. (PDF 809 kb)

\begin{abstract}
Abbreviations
AAC: Allowable annual cut; AM: Adaptive management; BC: British Columbia; BCMFLNRO: BC Ministry of Forests, Lands and Natural Resource Operations; BCMFML: BC Ministry of Forests, Mines and Lands; CSA: Canadian Standards Association; CSP: Clayoquot Scientific Panel; CWH: Coastal Western Hemlock; DEMO: Demonstration of Ecosystem Management Options; FPPR: Forest Planning and Practices Regulation; FREP: Forest and Range Evaluation Program; FRPA: Forest and Range Practices Act; FSC: Forest Stewardship Council; MASS: Montane Alternative Silvicultural Systems; MB: MacMillan Bloedel; SFI: Sustainable Forestry Initiative; STEMS: Silvicultural Treatments for Ecosystem Management in the Sayward; VI: Vancouver Island; VR: Variable retention; VRAM: Variable Retention Adaptive Management; Western: Western Forest Products
\end{abstract}

\section{Acknowledgments}

The authors thank the foresters, forestry engineers, planners and forest workers in BC for successfully taking up the challenge to implement variable retention and to do it safely. We are grateful to the many authors of cited studies for their valuable contributions to this topic, especially Sue Grayston, Isobel Pearsall, Dave Huggard, Anne Chan-McLeod, Louise deMontigny, Nancy Densmore, Christina Ovaska, Colin Peters, Michael Preston, Terry Rollerson, Jeff Sandford, Nick Smith, Lennart Sopuck and Elke Wind. We also thank Bryce Bancroft, Fred Bunnell, Laurie Kremsater, Ken Lertzman, Ken Zielke and many others who have worked to bring practical changes to silvicultural practices in BC's forests. We thank Carlos Acosta for preparing the diagrams of the VRAM experiments in Fig. A1. Funding for many studies cited was provided by the forest companies involved, the BC Forest Investment Account, Land Based Investment Program and Forest Science Program. Finally, we thank Guillermo Martínez Pastur and Jerry Franklin for encouraging us to write this overview paper, and we thank two anonymous reviewers for suggestions that improved the manuscript.

\section{Funding}

Funding for reported studies with which the authors are or have been associated was provided by the Province of British Columbia (BC Ministry of Forests, Lands, Natural Resource Operations and Rural Development; BC Forest Investment Account, Land Based Investment Program; BC Forest Science Program), the University of British Columbia and forest companies (Cascadia Forest Products, MacMillan Bloedel Limited, Western Forest Products Inc., Weyerhaeuser Company). Other than the scientists and field personnel directly involved in the research, the funding bodies did not have a role in the design of the studies, in the collection, analysis, and interpretation of data, and in writing the manuscript.

\section{Availability of data and materials}

The datasets used and/or analyzed during the current study are available from the corresponding author on reasonable request.

\section{Authors' contributions}

WJB was the lead author in writing and editing the manuscript and preparing figures, except Fig. A1 as noted in the acknowledgements; JD provided text and data for Western Forest Products' Forest Strategy, particularly 'History of VR adoption and spread in $\mathrm{BC}^{\prime}$ and 'The Forest Strategy_ongoing implementation by Western Forest Products Inc.'; BGD was the primary author of 'The Forest Project/Coast Forest Strategy' on the design of adaptive management and monitoring and a major contributor to the conclusions; SJM was the primary author of 'Wind damage to retention and cutblock edges' and was a major contributor to the introduction and to editing of the entire manuscript; TJP was the primary author of 'Effects on invertebrates and below-ground diversity'. All authors read and approved the final manuscript.

\section{Ethics approval and consent to participate} Not applicable.

\section{Consent for publication}

The authors consent to publish the data included in this paper.

\section{Competing interests}

The authors declare that they have no competing interests.

\section{Author details}

${ }^{1}$ Vancouver Island University, 900 Fifth Street, Nanaimo, BC V9R 5S5, Canada. ${ }^{2}$ Western Forest Products, 118-1334 Island Hwy., Campbell River, BC V9W 8C9, Canada. ${ }^{3}$ Glen Dunsworth Ecological Consulting, 7857 Shangri-La Rd., Lantzville, BC VOR 2H0, Canada. ${ }^{4}$ University of British Columbia, 2424 Main Mall, Vancouver, BC V6T 1Z4, Canada. ${ }^{5}$ BC Min. of Forests, Lands and Nat. Res. Oper, 400-640 Borland St., Williams Lake, BC V2G 4T1, Canada.

Received: 11 April 2019 Accepted: 6 June 2019

Published online: 23 July 2019

\section{References}

Arnott JT, Beese WJ (1997) Alternatives to clearcutting in BC coastal montane forests. For Chron 73:670-678

Aubry KB, Halpern CB, Maguire DA (2004) Ecological effects of variable-retention harvests in the northwestern United States: the DEMO study. Forest Snow Landscape Res 78:119-137

Aubry KB, Halpern CB, Peterson CE (2009) Variable-retention harvests in the Pacific Northwest: a review of short-term findings from the DEMO study. For Ecol Manag 258:398-408

Baker SC, Halpern CB, Wardlaw TJ, Crawford RL, Bigley RE, Edgar GJ, Evans SA, Franklin JF, Jordan GJ, Karpievitch Y, Spies TA, Thomson RJ (2015) Short- and long-term benefits for forest biodiversity of retaining unlogged patches in harvested areas. For Ecol Manag 353:187-195

Baker SC, Read SM (2011) Variable retention silviculture in Tasmania's wet forests: ecological rationale, adaptive management and synthesis of biodiversity benefits. Aust For 74:218-232

Baker SC, Spies TA, Wardlaw TJ, Balmer J, Franklin JF, Jordan GJ (2013) The harvested side of edges: effect of retained forests on the re-establishment of biodiversity in adjacent harvested areas. For Ecol Manag 302:107-121 
Baldwin LK, Bradfield GE (2005) Bryophyte community differences between edge and interior environments in temperate rain-forest fragments of coastal British Columbia. Can J For Res 35:580-592

Basile M, Mikusiński G, Storch I (2019) Bird quilds show different responses to tree retention levels: a meta-analysis. Global Ecol and Conserv 18:e00615. https:// doi.org/10.1016/j.gecco.2019.e00615

BC Integrated Land Management Bureau (2000) Vancouver Island summary land use plan. Province of British Columbia. Accessed May 20, 2010. https://www2 gov.bc.ca/gov/content/industry/crown-land-water/land-use-planning/ regions/west-coast/vancouverisland-lup Accessed 17 Mar 2019

BC Ministry of Forests and Range (2012) Timber tenures in British Columbia: managing public forests in the public interest, $17 \mathrm{p} \mathrm{https://www2.gov.bc.ca/}$ assets/gov/farming-natural-resources-and-industry/forestry/timber-tenures/ timber_tenures_brochure_2012.pdf Accessed 17 Mar 2019

BC-FRPA (2002) Forest and Range Practices Act, SBC, chapter 69. http://www. bclaws.ca/EPLibraries/bclaws_new/document/ID/freeside/00_02069_01\#part1. Accessed 20 May 2010

BCMFML (2010) The State of British Columbia's Forests, 3rd ed. BC Ministry of Forests, Mines and Lands. Forest Practices and Investment Branch, Victoria, BC https://www2.gov.bc.ca/assets/gov/environment/research-monitoringand-reporting/reporting/envreportbc/archived-reports/sof_2010.pdf Accessed 30 Mar 2019

BCMFRNRO (2016) New regulations enact historic Great Bear Rainforest legislation. BC Ministry of Forests, Lands, Natural resource operations. News Release, 21.12.2016. https://news.gov.bc.ca/releases/2016FLNR0302-002869 Accessed 30 Mar 2019

Beese WJ (2001) Windthrow monitoring of alternative silvicultural systems in montane coastal forests. In: Windthrow assessment and management in British Columbia: proceedings of the windthrow researchers workshop, Richmond, BC, January 31-February 1, 2001. Compiled by Mitchell, SJ and Rodney, J pp 2-11 http://www.for.gov.bc.ca/HFD/library/documents/ windthrow.pdf. Accessed 31 Mar 2019.

Beese WJ (2013) Variable retention harvesting. In: Orians GH, Schoen JW (eds) North Pacific temperate rainforests. University of Washington Press, Seattle, WA, pp 227-252

Beese WJ, Bryant AA (1999) Effect of alternative silvicultural systems on vegetation and bird communities in coastal montane forests of British Columbia, Canada. For Ecol Manag 115:231-242

Beese WJ, Dunsworth BG, Smith NJ (2005) Variable retention adaptive management experiments: testing new approaches for managing British Columbia's coastal forests. In: Balancing ecosystem values: innovative experiments for sustainable forestry, Gen Tech Rept PNW-635, CE Peterson and DA Maguire. USDA Forest Service, PNW Res Stn, Portland, OR pp 55-64

Beese WJ, Dunsworth BG, Zielke K, Bancroft B (2003) Maintaining attributes of old-growth forests in coastal $B C$ through variable retention. For Chron 79:570-578

Beese WJ, Rollerson TP, Peters CM (2019) Quantifying wind damage associated with variable retention harvesting in coastal British Columbia. For Ecol Manag 443:117-131

Bormann BT, Spaltenstein H, McCleellan MH, Ugolini FC, Cromack K Jr, Nay SM (1995) Rapid soil development after windthrow disturbance in pristine forests. J Ecol 83:747-757

Bruenig EF, Klemp CF (2000) Economic and ecological risk management in nearnatural forestry. In: Stewart GH, Benecke U, Hickey J (eds) Sustainable management of indigenous forest. Proceedings of a symposium held at Southern Connection Congress III, Lincoln University 17-22 January 2000. Wickliffe Press, Christchurch NZ, pp 2-15

Bunnell FL, Dunsworth BG (2004) Making adaptive management for biodiversity work-the example of Weyerhaeuser in coastal British Columbia. For Chron 80:37-43

Bunnell FL, Dunsworth BG (eds) (2009) Forestry and biodiversity: learning how to sustain biological diversity in managed forests. UBC Press, Vancouver, BC

Bunnell, FL, Kremsater, LL, Boyland, M (1998) An ecological rationale for changing forest management on MacMillan Bloedel's forest tenure. Publication R-22. Centre for Applied Conservation Biology, University of British Columbia. https://www.researchgate.net/publication/283350932_An_ecological_ rationale_for_changing_forest_management_on_MacMillan_Bloedel's_ forest_tenure. Accessed 31 Mar 2019

Bunnell FL, Kremsater LL, Wind E (1999) Managing to sustain vertebrate diversity in forests of the Pacific Northwest: relationships within stands. Env Rev 7:97-146
Bunsha D (2012) Two approaches to ecosystem-based management in British Columbia. Master of Resource Management thesis, School of Resource and Environmental Management, Simon Fraser University, Burnaby http://summit. sfu.ca/item/12592. Accessed 30 May 2019

Byrne KE, Mitchell SJ (2013) Testing of WindFIRM/ForestGALES_BC: a hybrid-mechanistic model for predicting windthrow in partially harvested stands. Forestry 86:185-199

Chan-McLeod, A (2008) An experimental study of variable-retention harvest methods on forest birds. Executive summary, UBC Faculty of Forestry, Vancouver, BC, project Y081156, BC Forest Investment Account, Forest Science Program: https://www.for.gov.bc.ca/hfd/library/FIA/2008/FSP_ Y081156.pdf Accessed 30 May 2019

Chipello, CJ (1998) MacMillan to end clear-cutting; environmentalists hail decision. Wall Street J https:/www.wsj.com/articles/SB897521206223486500 Accessed 30 Mar 2019

Chisholm B (2013) Early occupation and forest resource use in prehistoric British Columbia. In: Tindall DB, Trosper RL, Perreault P (eds) Aboriginal peoples and forest lands in Canada. UBC Press, Vancouver, BC, pp 151-160

Churchland CT (2013) Green-tree-retention harvesting as a tool to maintain soil microbial diversity and function in harvested forests. PhD thesis, University of British Columbia, Vancouver, BC https://open.library.ubc.ca/clRcle/collections/ ubctheses/24/items/1.0074004 Accessed 30 May 2019

Clausen DL, Schroeder RF (2004) Social acceptability of alternatives to clearcutting: discussion and literature review with emphasis on southeast Alaska. Gen Tech Rep PNW-GTR-594. USDA Forest Service, Pacific Northwest Research Station, Portland

Coady $L$ (2000) What I saw of the revolution: reflections of a corporate environmental manager in the 1990s BC coastal forest industry. For Chron 76:263-274

Coast Funds (2019) Coastal stewardship network: collaborative monitoring and protection of First Nations' lands and waters. https://coastfundsca/stories/ coastal-first-nations-sharing-intelligence-through-the-coastal-stewardshipnetwork/. Accessed 30 Mar 2019

Coast Information Team (2004) Ecosystem-based management planning handbook. Cortex Consultants, Victoria, BC https://www.for.gov.bc.ca/tasb/ slrp/citbc/c-ebm-hdbk-fin-22mar04.pdf. Accessed 31 Mar 2019

Côté P, Tittler R, Messier C, Kneeshaw DD, Fall A, Fortin MJ (2010) Comparing different forest zoning options for landscape-scale management of the boreal forest: possible benefits of the TRIAD. For Ecol Manag 259:418-427

Coxson DS, Stevenson SK (2007) Growth rate responses of Lobaria pulmonaria to canopy structure in even-aged and old-growth cedar-hemlock forests of central-interior British Columbia, Canada. For Ecol Manag 242:5-16

Craig A, Macdonald SE (2009) Threshold effects of variable retention harvesting on understory plant communities in the boreal mixedwood forest. For Ecol Manag 258:2619-2627

CSP (1994) Report of the scientific panel for sustainable forest practices in Clayoquot Sound. Cortex Consultants, Victoria, BC http://www.llbc.leg.bc.ca/ public/PubDocs/bcdocs/158782/clay1.pdf. Accessed 15 Mar 2019

CSP (1995) Sustainable ecosystem management in Clayoquot Sound: planning and practices. Report 5, Scientific Panel for Sustainable Forest Practices in Clayoquot Sound. Cortex Consultants, Victoria, BC, p 296 http://blogs.ubc.ca/ apfnet01/files/2015/08/Clayoquot_Science_Panel_Report-5-Sustainable_ Ecosystem_Management.pdf Accessed 15 Mar 2019

D'Amato AW, Palik BJ, Franklin JF, Foster DR (2017) Exploring the origins of ecological forestry in North America. J Forestry 115:126-127

D'Anjou B (2003) Single-tree and group selection harvesting in an old-growth forest on the west coast of Vancouver Island, British Columbia. Technical Report TR-024. BC Ministry of Forests, Vancouver Forest Region, Nanaimo, BC

Daniels LD, Gray RW (2006) Disturbance regimes in coastal British Columbia. BC J Ecosyst Manage 7(2):44-56

deMontigny LE, Nigh GD (2009) Silviculture treatments for ecosystem management in the Sayward (STEMS): establishment report for STEMS 2, Elk Bay. Tech Rep 049, BC Min For Range, Res Br, Victoria, BC https://www.for. gov.bc.ca/hfd/pubs/Docs/Tr/Tr049.pdf. Accessed 27 May 2019

Deal JA (2005) Monitoring the effectiveness of conservation strategies: TFL 37 case study. In: Biodiversity in forested ecosystems: management approaches and monitoring for effectiveness. University of British Columbia. FORREX workshop, December 6-7 2005

Deal RL, Tappeiner JC (2002) The effects of partial cutting on stand structure and growth of western hemlock-Sitka spruce stands in southeast Alaska. For Ecol Manag 159:173-186

DellaSala DA, Hagar J, Engel KA, McComb WC, Fairbanks RL, Campbell EG (1996) Effects of silvicultural modifications of temperate rainforest on breeding and wintering bird communities, Prince of Wales Island, southeast Alaska. Condor 98:706-721 
Densmore N (2011) Coastal Forest Region: analysis of stand-level biodiversity sampling results in six predominant biogeoclimatic subzones. Forest and Range Evaluation Program, Report No. 30, BC Min For, Lands and Nat Res Oper, For Pract Invest Br, Victoria, BC https://www2.gov.bc.ca/assets/gov/ farming-natural-resources-and-industry/forestry/frep/frep-docs/frep_report_ 30.pdf?fileName=frep_report_30.pdf. Accessed 26 June 2019

Dewi M (2009) Soil microbial community responses to green-tree-retention harvesting in coastal British Columbia. MSc Thesis. The University of British Columbia https://open.library.ubc.ca/clRcle/collections/ubctheses/24/items/1. 0070829 Accessed 30 May 2019

Environmental Reporting BC (2018) Trends in timber harvest in B.C. Ministry of Forests, lands, natural resource operations and rural development, British Columbia http://www.env.gov.bc.ca/soe/indicators/land/timber-harvest.html Accessed 15 Mar 2019

Fedrowitz K, Koricheva J, Baker SC, Lindenmayer DB, Palik B, Rosenvald R, Beese W, Franklin JF, Kouki J, Macdonald E, Messier C, Sverdrup-Thygeson A, Gustafsson L, Baraloto C (2014) Can retention forestry help conserve biodiversity? A metaanalysis. J Appl Ecol 51:1669-1679. https://doi.org/10.1111/1365-2664.12289

Forest Products Association of Canada (2019) Forest management certification in Canada: 2018 year-end status report for British Columbia, 8 p http:// certificationcanada.org/wp-content/uploads/2019/02/2018-Yearend-SFMCertification-Detailed-Report-BC.pdf. Accessed 17 Mar 2019

FPC (1999) Forest Practices Code of British Columbia Act, Operational Planning Regulations. SBC, c 41

FPPR (2004) Forest Planning and Practices Regulation, Wildlife tree retention, Part 4, Div. 5, Sec. 66, BC Reg 14/2004. http://www.bclaws.ca/civix/document/id/ complete/statreg/14_2004\#section66. Accessed 12 Feb 2019

Franklin JF, Berg DR, Thornburgh DA, Tappeiner JC (1997) Alternative silvicultural approaches to timber harvesting: variable retention harvest systems. In: Kohn KA, Franklin JF (eds) Creating a forestry for the 21st century: the science of ecosystem management. Island Press, Washington, DC, pp 111-139

Franklin JF, Johnson KN, Johnson DL (2018) Ecological forest management. Waveland Press Inc, Long Grove, IL

FREP (2016) Forest and range evaluation program, assistant deputy minister resource stewardship report: regional results of the Forest and range evaluation program, FREP Report No. 41, Resource Stewardship Division, BC Min Forest, Lands and Natural Resource Operations, Victoria, BC, 79 p. https:// www2.gov.bc.ca/assets/gov/farming-natural-resources-and-industry/forestry/ frep/frep-docs/reports/adm_resource_stewardship_report_frep_results_2016. pdf Accessed 30 Mar 2019

Gitzen RA, West SD, Maguire CC, Manning T, Halpern CB (2007) Response of terrestrial small mammals to varying amounts and patterns of green-tree retention in Pacific Northwest forests. For Ecol Manag 251:142-155. https:// doi.org/10.1016/j.foreco.2007.05.028

Grayston, S, Addison, J, Berch, S, deMontigny, L, Dural, D, Egger, K, Jones, M, Lemieux, J, Modesto, R, Mohn, W, Panesar, T, Prescott, C, Simard, S, Srivastava, D (2005) Potential of green-tree retention as a tool to maintain soil function after harvest, poster abstract, In: balancing ecosystem values: innovative experiments for sustainable forestry, Gen Tech Rept PNW-635, CE Peterson and DA Maguire (eds), USDA Forest Service, PNW Res Stn, Portland, OR pp 353-355. https://www.for.gov. bc.ca/hfd/library/FIA/2007/FSP_Y073049c.pdf. Accessed 30 May 2019

Greig LA, Marmorek DR, Murray C, Robinson DCE (2013) Insight into enabling adaptive management. Ecol Soc 18(3):24. https://doi.org/10.5751/ES-05686-180324

Groot A, Lussier J-M, Mitchell AK, Maclsaac DA (2005) A silvicultural systems perspective on changing Canadian forestry practices. For Chron 81:50-55

Gustafsson L, Baker S, Bauhus J, Beese W, Brodie A, Kiehl B, Kouki J, Lindenmayer D, Lõhmus A, Martínez-Pastur G, Messier C, Neyland M, Palik B, SverdrupThygeson A, Volney J, Wayne A, Franklin J (2012) Retention forestry to maintain multifunctional forests: a world perspective. BioScience 62:633-645

Halpern CB, Halaj J, Evans SA, Dovčiak M (2012) Level and pattern of overstory retention interact to shape long-term responses of understories to timber harvest. Ecol Appl 22:2049-2064

Helms JA (1998) The dictionary of forestry. Society of American Foresters, Bethesda, MD Hennon PE, DeMars D (1997) Development of wood decay in wounded western hemlock and Sitka spruce in Southeast Alaska. Can J For Res 27:1971-1978

Holling CS (1978) Adaptive environmental assessment and management. Wiley, New York

Holloway, GL, Smith, WP, Halpern, CB, Gitzen, RA, Maguire, CC, West, SD (2012) Influence of forest structure and experimental green-tree retention on northern flying squirrel (Glaucomys sabrinus) abundance. For Ecol Manag 285: 187-194. https://doi.org/10.1016/j.foreco.2012.08.025
Huggard, DJ (2005) Habitat monitoring 1999 to 2005-summary and data report, Coast Forest Strategy, Adaptive Management Program, BC Forest Investment Account, Land Based Investment Program, Project 6453008, 144 p. https://www for.gov.bc.ca/hfd/library/FIA/2005/LBIP_6453008.PDF. Accessed 30 May 2019

Huggard DJ (2006) Habitat monitoring 1999 to 2006_summary and data report, Coast Forest Strategy, Adaptive Management Program, BC Forest Investment Account, Land Based Investment Program, Project 6453008

Huggard DJ, Bunnell FL, Kremsater LL (2009a) Sustaining forested habitat. In: Bunnell FL, Dunsworth BG (eds) Forestry and biodiversity: learning how to sustain biological diversity in managed forests. UBC Press, Vancouver, BC, pp 117-151

Huggard DJ, Sandford J, Kremsater LL (2009b) Learning from habitat elements. In: Bunnell FL, Dunsworth BG (eds) Forestry and biodiversity: learning how to sustain biological diversity in managed forests. UBC Press, Vancouver, BC, pp 152-172

Hunter ML Jr, Calhoun A (1996) A TRIAD approach to land-use allocation. In: Szaro RC, Johnstone DW (eds) Biodiversity in managed landscapes. Oxford University Press, Oxford, pp 477-491

Hunter ML (1990) Wildlife, forests, and forestry: principles of managing forests for biological diversity. Prentice-Hall, Englewood Cliffs, NJ.

lles K, Smith NJ (2006) A new type of sample plot that is particularly useful for sampling small clusters of objects. For Sci 52:148-154

Jones MD, Twieg BD, Durall DM, Berch SM (2008) Location relative to a retention patch affects the ECM fungal community more than patch size in the first season after timber harvesting on Vancouver Island. British Columbia For Ecol Manage 255:1342-1352. https://doi.org/10.1016/j.foreco.2007.10.042

Keenan RJ, Kimmins JP (1993) The ecological effects of clear-cutting. Environ Rev 1:121-144

Kirchoff MD, Schoen JW (1987) Forest cover and snow: implications for deer habitat in southeast Alaska. J Wildlife Manage 51:28-33

Klinka K, Pojar J, Meidinger DV (1991) Revision of biogeoclimatic units of coastal British Columbia. Northwest Science 65:32-78

Kramer MG, Hansen AJ, Taper ML, Kissinger EJ (2001) Abiotic controls on longterm windthrow disturbance and temperate rain forest dynamics in southeast Alaska. Ecology 82:2749-2768

Kramer MG, Sletten RS, Sollins P (2004) Soil carbon dynamics along a windthrow disturbance sequence in southeast Alaska. Ecology 85:2230-2244

Kranabetter JM, deMontigny L, Ross G (2013) Effectiveness of green-tree retention in the conservation of ectomycorrhizal fungi. Fungal Ecol 6:430438. https://doi.org/10.1016/j.funeco.2013.05.001

Kremsater LL, Bunnell FL, Huggard D, Dunsworth BG (2003) Indicators to assess biological diversity: Weyerhaeuser's coastal British Columbia forest project. For Chron 79:590-601

Leckie SE, Prescott CE, Grayston SJ, Neufeld JD, Mohn WW (2004) Characterization of humus microbial communities in two adjacent forest types that differ in nitrogen availability. Microb Ecol 48:29-40

Lemieux JP, Lindgren BS (2004) Ground beetle responses to patch retention harvesting in high elevation forests of British Columbia. Ecography 27:557566. https://doi.org/10.1111/j.0906-7590.2004.03888.x

Lilles E, Dhar A, Coates KD, Haeussler S (2018) Retention level affects dynamics of understory plant community recovery in northern temperate hemlock-cedar forests. For Ecol Manag 421:3-15

Lindenmayer D, Franklin J, Lõhmus A, Baker S, Bauhus J, Beese W, Brodie A, Kiehl B, Kouki J, Martínez-Pastur G, Messier C, Neyland M, Palik B, SverdrupThygeson A, Volney J, Wayne A, Gustafsson L (2012) A major shift to the retention approach for forestry can help resolve some global forest sustainability issues. Cons Letters 5:421-431

Lindenmayer DB, Franklin JF (2002) Conserving forest biodiversity. Island Press, Washington, DC

Lindenmayer DB, Wood J, McBurney L, Blair D, Banks SC (2015) Single large versus several small: the SLOSS debate in the context of bird responses to a variable retention logging experiment. For Ecol Manag 339:1-10

MacLean DA, Seymour RS, Montigny MK, Messier C (2008) Allocation of conservation efforts over the landscape: the TRIAD approach. In: Villard M-A, Jonsson BG (eds) Setting conservation targets for managed forest landscapes. Cambridge Univ Press, UK

Macy H (2011) The four storey forest: as grows the trees, so too the heart. Poplar Publishing, Courtenay, BC

Maguire DA, Canavan S, Halpern CB, Aubry KB (2005a) Fate of taxa after variableretention harvesting in Douglas-fir forests of the northwestern United States. In: Peterson CE, Maguire DA (eds) Balancing ecosystem values: innovative experiments for sustainable forestry, Gen. Tech. Rept. PNW-635. USDA Forest Service, PNW Res Stn, Portland, OR, pp 271-279 
Maguire DA, Halpern CB, Phillips DL (2007) Changes in forest structure following variable-retention harvests in Douglas-fir dominated forests. For Ecol Manag 242:708-726

Maguire DA, Manning T, West SD, Gitzen RA (2005b) Green-tree retention in managed forests: post-harvest responses of salamanders. In: Peterson CE, Maguire DA (eds) Balancing ecosystem values: innovative experiments for sustainable forestry, Gen. Tech. Rept. PNW-635. USDA Forest Service, PNW Res Stn, Portland, OR, pp 265-270

McClellan MH, Hennon PE (2005) Maintaining old-growth features in forests used for wood production in southeast Alaska. In: Peterson CE, Maguire DA (eds) Balancing ecosystem values: innovative experiments for sustainable forestry, Gen. Tech. Rept. PNW-635. USDA Forest Service, PNW Res Stn, Portland, OR, pp 127-133

Mitchell AK, Koppenaal R, Goodmanson G, Benton R, Bown T (2007) Regenerating montane conifers with variable retention systems in a coastal British Columbia forest: 10-year results. For Ecol Manag 246:240-250

Mitchell SJ (2013) Wind as a natural disturbance agent in forests: a synthesis. Forestry 86:147-157

Mitchell SJ, Beese WJ (2002) The retention system: reconciling variable retention with the principles of silvicultural systems. For Chron 78:397-403

Molina R, Pilz D, Smith J, Dunham S, Dreisbach T, O'Dell T, Castellano M (2001) Conservation and management of forest fungi in the Pacific Northwestern United States: an integrated ecosystem approach. In: Moore D, Nauta MM, Evans SE, Rotheroe M (eds) Fungal conservation: issues and solutions. A special volume of the British Mycological Society. Cambridge University Press, Cambridge, UK

Montigny MK, MacLean DA (2006) Triad forest management: scenario analysis of forest zoning effects on timber and non-timber values in New Brunswick, Canada. For Chron 82:496-511

Mychajlowycz M (2010) Overview of logging in Clayoquot Sound: 2000-2009. Terrestrial Committee, Clayoquot Biosphere Trust (April 2010 update) http:// focs.ca/wp-content/uploads/2012/07/Clayoquot-Logging-Report-2009-wApr2010-update.pdf. Accessed 31 Mar 2019

Nowacki GJ, Kramer MG (1998) The effects of wind disturbance on temperate rain forest structure and dynamics of southeast Alaska. USDA Forest Service, PNW Res Stn, Gen Tech Rep PNW-GTR-421, Portland, OR

Outerbridge RA, Trofymow JA (2004) Diversity of ectomycorrhizae on experimentally planted Douglas-fir seedlings in variable retention forestry sites on southern Vancouver Island. Can J Botany 82:1671-1681. https://doi. org/10.1139/b04-134

Outerbridge RA, Trofymow JA (2009) Forest management and maintenance of ectomycorrhizae: a case study of green tree retention in South-Coastal British Columbia. BC J Ecos Manage 10:23

Ovaska K, Sopuck L, Robichaud D (2016) Short-term effects of variable-retention logging practices on terrestrial gastropods in coastal forests of British Columbia. Northwest Science 90:260-277. https://doi.org/10.3955/046.090.0304

Palik BJ, D’Amato AW (2017) Ecological forestry: much more than retention harvesting. J Forestry 115:51-53

Palik BJ, Mitchell RJ, Hiers J (2002) Modeling silviculture after natural disturbance to maintain biological diversity in the longleaf pine (Pinus palustris) ecosystem: balancing complexity and implementation. For Ecol Manag 155:347-356

Pearce JL, Venier LA (2006) The use of ground beetles (Coleoptera: Carabidae) and spiders (Araneae) as bioindicators of sustainable forest management: a review. Ecol Indic 6:780-793. https://doi.org/10.1016/j.ecolind 2005 Mar 005

Pearsall IA (2007) Study to assess ground beetles (Coleoptera: Carabidae) as ecological indicators in WFP's Port McNeill operational and experimental sites: effects of patch size. Pearsall Ecological Consulting, Nanaimo, BC. Year 6 final report. BC Forest Science Program Project No. Y091065 https://www.for. gov.bc.ca/hfd/library/FIA/2007/FSP_Y072029b.pdf. Accessed 30 May 2019

Pearsall IA, Beese WJ (2009) Effect of stand-level structures and configurations on carabid beetles in coastal B.C. VR sites: comparison of riparian retention and group retention VR methods. Executive Summary, Project Y091065, BC Forest Investment Account, Forest Science Program https://www.for.gov.bc.ca/hfd/ library/FIA/2009/FSP_Y091065.pdf. Accessed 30 May 2019

Pearson A (2010) Natural and logging disturbances in the temperate rain forests of the central coast, British Columbia. Can J For Res 40:1970-1984

Phillips E (1996) Comparing silvicultural systems in a coastal montane forest: productivity and cost of harvesting operations., FRDA Rep. 247. BC Ministry of Forests, Victoria, BC https:/wnw.for.gov.bc.ca/hfd/pubs/docs/Frr/Frr247.pdf Accessed 31 March 2019

Philpott TJ, Barker JS, Prescott CE, Grayston SJ (2018) Limited effects of variableretention harvesting on fungal communities decomposing fine roots in coastal temperate rainforests. Appl Environ Microbiol 84. https://doi.org/10. 1128/AEM.02061-17
Preston MI, Harestad AS (2007) Community and species responses by birds to group retention in a coastal temperate forest on Vancouver Island, British Columbia. For Ecol Manag 243:156-167

Price K, Roburn A, MacKinnon A (2009) Ecosystem-based management in the Great Bear Rainforest. For Ecol Manage 258:495-503

Private Managed Forest Land Act (2003) SBC, Chapter 80. http://www.bclaws.ca/ civix/document/id/complete/statreg/03080_01 Accessed 30 May 2019

Province of BC (1995) Biodiversity guidebook. BC Ministry of Forests and BC Environmenbt, Victoria, BC https://www.for.gov.bc.ca/hfd/library/documents/ bib19715.pdf. Accessed 29 Mar 2019

Province of BC (2008) Order establishing land use objectives for Clayoquot Sound. BC Ministry of Agriculture and Lands, Victoria, BC https://www.for.gov. bc.ca/ftp/DSI/external/!publish/Stewardship/SIFD_Objectives_Matrix/Other_ Supporting_Documents/Clayoquot_LUO_Order/Order_establishing_LUO_ for_Clayoquot_Sound_May_28_2008.pdf. Accessed 17 Mar 2019

Province of BC (2014) Haida Gwaii Land Use Objectives Order: consolidated version. BC Min of Forests, Lands and Natural Resource Operations, Victoria, BC https://www2.gov.bc.ca/assets/gov/farming-natural-resources-andindustry/natural-resourceuse/land-water-use/crown-land/land-use-plans-andobjectives/westcoast-region/haidagwaii-slua/haidagwaii_slua_luor_ 8may2014consolidated.pdf. Accessed 15 Mar 2019

Province of BC (2016) Great Bear Rainforest Land Use Objectives Order: background and intent. BC Min of Forests, Lands and Natural Resource Operations, Victoria, BC https://www2.gov.bc.ca/assets/gov/farming-naturalresources-andindustry/natural-resource-use/land-water-use/crown-land/landuse-plans-and-objectives/westcoast-region/great-bear-rainforest/great_bear_ land_use_order_background_intent.pdf. Accessed 15 Mar 2019

Province of BC (2019) Silviculture statistics. BC Min of Forests, Lands and Natural Resource Operations, and Rural Development, Victoria, BC https:// www2govbcca/gov/content/industry/forestry/managing-our-forest-resources/ silviculture/silviculture-statistics Accessed 15 Mar 2019

Ribe RG (2009) In-stand scenic beauty of variable retention harvests and mature forests in the U.S. Pacific northwest: the effects of basal area, density, retention pattern and down wood. J Environ Manag 91:245-260

Roberts MW, D'Amato AW, Kern CC, Palik BJ (2016) Long-term impacts of variable retention harvesting on ground-layer plant communities in Pinus resinosa forests. J Appl Ecol 53:1106-1116

Rosenvald R, Lõhmus A (2008) For what, when, and where is green-tree retention better than clear-cutting? A review of biodiversity aspects. For Ecol Manag 255:1-15. https://doi.org/10.1016/j.foreco.2007.09.016

Scott RE, Mitchell SJ (2005) Empirical modelling of windthrow risk in partially harvested stands using tree, neighbourhood, and stand attributes. For Ecol Manag 218:193-209. https://doi.org/10.1016/j.foreco.2005.07.012

Sheppard SRJ, Meitner MJ (2005) Using multi-criteria analysis and visualization for sustainable forest management planning with stakeholder groups. For Ecol Manag 207:171-187

Sillett SC, McCune B, Peck JE, Rambo TR, Ruchty A (2000) Dispersal limitations of epiphytic lichens result in species dependent on old-growth forests. Ecol Appl 10:789-799

Smith NJ, Beese WJ (2012) Effects of low levels of dispersed retention on the growth and survival of young, planted Douglas-fir. Forests 3:230-243. https:// doi.org/10.3390/f3020230

Soler R, Schindler S, Lencinas MV, Peri PL, Martínez Pastur G (2016) Why biodiversity increases after variable retention harvesting: a meta-analysis for southern Patagonian forests. For Ecol Manage 369:161-169. https://doi.org/ 10.1016/j.foreco.2016.02.036

Stankey GH, Clark RN, Bormann BT (2005) Adaptive management of natural resources: theory, concepts, and management institutions. Gen Tech Report PNW-GTR-654. USDA Forest Service, PNW Res Stn, Portland, OR

Steventon JD (2011) Retention patches: windthrow and recruitment of habitat structure 12-16 years after harvest. BC J Ecosyst Manage 11:18-28

Sullivan TP, Sullivan DS (2011) Balancing pest management and forest biodiversity: vole populations and habitat in clearcut vs. variable retention harvested sites. Crop Prot 30:833-843

Sullivan TP, Sullivan DS (2018) Green-tree retention and recovery of an old-forest specialist, the southern red-backed vole (Myodes gapperi), 20 years after harvest. Wildl Res 44:669-680

Taan Forest (2018) Annual Monitoring Report 2017, FSC Management Plan, Additional file 1: Appendix 3, p 164. https://www.taanforest.com/application/ files/6115/3808/2740/FSCMP_App3_MonitoringReport2017_May18x.pdf. Accessed 30 Mar 2019. 
Tindall DB, Robinson JL (2017) Collective action to save the ancient temperate rainforest: social networks and environmental activism in Clayoquot Sound. Ecol Soc 22(1):40. https://doi.org/10.5751/ES-09042-220140

Trofymow JA, Addison J, Blackwell BA, He F, Preston CA, Marshall VG (2003) Attributes and indicators of old growth and successional Douglas-fir forests on Vancouver Island. Environ Rev 11:S187-S204

Urgenson LS, Halpern CB, Anderson PD (2013) Twelve-year responses of planted and naturally regenerating conifers to variable-retention harvest in the Pacific Northwest, USA. Can J For Res 43:46-55

Van Kooten GC, Nelson HW, Vertinsky I (2005) Certification of sustainable forest management practices: a global perspective on why countries certify. For Policy and Econ 7:857-867

Vyse A, Mitchell AK, deMontigny L (2005) Seeking alternatives to clearcutting in British Columbia: the role of large-scale experiments for sustainable forestry. In: Balancing ecosystem values: innovative experiments for sustainable forestry, Gen. Tech. Rept. PNW-635, C.E. Peterson and D.A. Maguire (eds), USDA Forest Service, PNW Res Stn, Portland, OR, pp 155-163 www.cfs.nrcan. gc.ca/pubwarehouse/pdfs/25519.pdf. Accessed 29 Mar 2019

Walters CJ (2007) Is adaptive management helping to solve fisheries problems? Ambio 36:304-307

Western (2018) 2018 Sustainability report, Western Forest Products, Vancouver, BC https://www.westernforest.com/responsibility/environment/. Accessed 31 Mar 2019

Whyte BJ, Halpern CB (2019) Forest aggregates influence conifer recruitment and height growth in a long-term variable-retention experiment. For Ecol Manag 441:42-56. https://doi.org/10.1016/jforeco.2019.01.039

Wiensczyk AM (2012) Status of British Columbia's long-term silvicultural systems research trials. FORREX Forum for Research and Ext in Nat Res, Kamloops, BC File Report 12-01 https://www.for.gov.bc.ca/ftp/rsi/external//publish/ Dry\%20Fir\%20Committee/Literature\%20Review/Management/Wiensczyk 2012_StatusOfBCsLongTermSilvSystemResearch.pdf. Accessed 25 June 2019

Wilk RJ (2019) Effects of variable-retention treatments on numbers of singing small passerine birds in Pacific Northwest forests. Northwest Nat 100:60-70. https://doi.org/10.1898/NWN18-19

Wind E (2008) Amphibians as indicators of wetland habitat conservation under variable retention harvesting. Final technical report, project Y083027, BC Forest Investment Account, Forest Science Program, p 26 https://www.for. gov.bc.ca/hfd/library/FIA/2008/FSP_Y083027.pdf Accessed 30 May 2019

Wind E, Beese B (2008) Little known and little understood: development of a small wetland assessment field card to identify potential breeding habitat for amphibians. BC J Ecos Manage 9:47-49

Zielke K, Bancroft B, Swift K, Turner J (2008) British Columbia's coastal forests: variable retention decision aid for biodiversity habitat and retention. $\mathrm{BC}$ Ecos Manage 9:1-4

\section{Publisher's Note}

Springer Nature remains neutral with regard to jurisdictional claims in published maps and institutional affiliations.

\section{Submit your manuscript to a SpringerOpen ${ }^{\circ}$ journal and benefit from:}

- Convenient online submission

- Rigorous peer review

- Open access: articles freely available online

- High visibility within the field

- Retaining the copyright to your article

Submit your next manuscript at $\boldsymbol{\nabla}$ springeropen.com 